\title{
The social space of Muslim spokespersons in India: A typology
}

\author{
Julien Levesque \\ Visiting Assistant Professor, Ashoka University \\ Laurence Gautier \\ Researcher, Centre de Sciences Humaines \\ Nicolas Belorgey \\ Research fellow, IRISSO, CNRS
}

\begin{abstract}
Who speaks for Muslims in India? Who are the leaders of the so-called "Muslim organizations"? What family and educational background do they come from? What is their relation to state authorities? This article addresses these questions by presenting a unique biographical database and the results of statistical treatments (multiple correspondence analysis and hierarchical clustering on principal components) of this data. This database includes the office-bearers of a selected set of organizations that make representative claims in the name of Muslims in India. Our analysis thus delineates the contours of the social space of Muslim spokespersons in India and describes how it is structured. We will highlight the important distinctions that exist among these Muslim spokespersons, such as the opposition between secular figures and religious scholars, the political sphere and the educational sphere, and between central power and regional dynamics. This analysis allows us, more broadly, to examine the role of state authorities in the definition of the Muslim spokespersons, thus highlighting some of the characteristic features of state secularism in India.
\end{abstract}




\section{Introduction}

Who are Muslim spokespersons in India? Academic as well as non-academic publications frequently use the notion of "Muslim leader", sometimes alternatively with the notion of "Muslim elites" to refer to individuals who claim to speak for Indian Muslims. These terms carry a set of implicit assumptions, which are seldom discussed explicitly. Instead, authors tend to use these notions as if they were self-evident, but the very fact that the notions of "Muslim leader" and "Muslim elites" can be used alternatively shows the lability of these categories and points to the absence of clear conceptual boundaries. ${ }^{1}$ It also suggests that none of these terms may be fully satisfactory to characterise the set of individuals who claim to speak for Indian Muslims.

This article aims to fill this gap by proposing a definition and an analysis of the social space of India's Muslim spokespersons. By Muslim spokespersons, we mean the set of individuals who have the capacity to claim to represent Muslims and to receive from the state a certain degree of recognition for that claim. We have chosen to use the term "spokesperson", which we consider to be both more accurate and more comprehensive than "elites" or "leaders". Indeed, the term "elites" refers to socio-economic groups endowed with a high social status, economic and political power and/or cultural capital, but it need not refer to individuals who aim to speak for others. As for the term "leader", it usually refers to figures who can mobilize a group of followers, get them to do something (Ahlquist and Levi, 2011) and possibly deliver public goods (Kitschelt and Wilkinson, 2007). The problem is that in the Indian context, the term "Muslim leader" is often used loosely to refer to a set of individuals who may claim to speak for Muslims, but who do not necessarily have the capacity to pull crowds nor to direct

\footnotetext{
${ }^{1}$ Theodore Wright (1964) speaks of "Muslim political elites" to refer to Muslim legislators, while acknowledging that other types of public figures may exert influence within the Muslim community. But these lie outside the scope of his study. Brass (1974) and Hasan (1997) both speak alternatively of elites and leaders. They highlight the existence of different types of Muslim leaders, but they do not provide a clear and explicit definition of what they mean by "leaders", nor do they rely on a systematic study of these leaders' profiles to construct their categories. More recently, Hilal Ahmed (2019: 153) has proposed a detailed definition of Muslim elites. According to him, Muslim elites correspond to "a class of economically rich, religiously dominant, politically influential and culturally powerful Muslims who articulate Muslim views on relevant issues and debates and seek legitimacy as representatives". In this way, Ahmed combines socio-economic criteria, commonly associated with elites, with representative claims, which need not be systematically associated with the notion of elites. To the word "elites", we prefer the term "spokesperson", which puts more explicit focus on representative claims.
} 
their actions. ${ }^{2}$ This is why our focus here is not so much on individuals' actual capacity to mobilize followers but rather on their "representative claims", to use Michael Saward's expression.

These spokespersons need not be professional politicians nor elected representatives. Saward argues that representation should be understood "in terms of claims to be representative by a variety of political actors, rather than (as is normally the case) ... as an achieved, or potentially achievable, state of affairs as a result of election" (Saward, 2006: 298). In line with Michael Saward's argument, we look at individuals who have the capacity to make "representative claims" beyond elections and representative mandates. ${ }^{3}$

The capacity to make "representative claims" is at least in part premised upon the state's recognition. Indeed, being able to make representative claims requires a certain legitimacy, which state authorities provide or recognise. ${ }^{4}$ Here, we understand the capacity to make representative claims as an attribute that an individual may possess but that usually rests in institutions and organizations. In other words, while popularity may endow with legitimacy and influence, holding an office in state-established or state-recognized institutions and organizations provides and reinforces the capacity to make representative claims. We thus define Muslim spokespersons as those who occupy institutional or organizational positions on the basis of which they claim to represent Muslims-or are deemed legitimate by the state to make representative claims in the name of Muslims. ${ }^{5}$

${ }^{2}$ Hilal Ahmed (2021) highlights this gap Muslim leaders' claims to speak for Muslims and their capacity to mobilise Muslim voters. Based on the results of the CSDS-Lokniti survey-based study on Politics and Society between elections (2017-2019) he shows that a significant portion of Muslim voters do not consider the candidates' religious identity to be a decisive factor. They tend to see Muslim politicians "primarily as professional politicians [sic] who follow the usual rule of the game" rather than as Muslim leaders primarily committed to the defence of their community.

${ }^{3}$ For an overview of the electoral representation of Muslims in India's lower house, see Farooqui (2020).

${ }^{4}$ This does not mean, of course, that the state is the only provider of legitimacy. The authority of members of the Muslim leadership also largely depends upon their perception among Indian Muslims. However, since we did not have a way of measuring this perception, and since we wished to focus on political representation, we gave prime importance to the organizations' relationship to the state in order to delineate our population.

${ }^{5}$ We will see later that these Muslim spokespersons do not necessarily make these claims themselves. 
In India, the role of the state in legitimizing certain individuals or groups as representatives for a specific community can be traced historically. The political notion of "Muslim community" emerged during the colonial period before the establishment of an electoral democracy. ${ }^{6}$ Colonial authorities perceived Indian society as a juxtaposition of separate religious or caste-based groups, each one led by their own elites, who were supposed to speak for their communities. ${ }^{7}$ The state's recognition of these elites was not primarily based on their being elected, but more on their social (and sometimes religious) status and on their capacity to organize themselves to petition the colonial state. ${ }^{8}$ Moreover, the trauma of partition largely undermined the legitimacy of Muslim political parties, seen as responsible for the division of the subcontinent. This was particularly true in North India, the former "Muslim heartland" (Kudaisya 2006), where communal tensions remained rife. In this context, Muslim political parties came to represent only one form of Muslim representative body recognized by the state.

\footnotetext{
${ }^{6}$ The All-India Muslim League, which claimed to speak for an all-India Muslim community, was established in 1906, at a time when elections were limited to municipal councils and rural boards, where only small groups of house proprietors and traders could vote, and to legislative councils, where indirect elections served to fill a minority of non-official seats. Colonial authorities saw these elections as "an instrument of political and popular education" that would allow them to "utilize" the "intelligent class of public spirited men", rather than as the foundation stone of a future parliamentary system (Chiriyankandath, 1992: 41). The founding members of AIML, who belonged to Muslim zamindari and professional elites, themselves had strong reservations against elected representation. They feared that a system of representation which would be based on "numerical importance" would undermine what had been Muslims' (read Muslim elites) "political importance” under Mughal and early colonial rule (see the Simla Deputation (1906)).
}

${ }^{7}$ On colonial ethnography or the colonial state's “ordering of difference", see for instance Bayly (1999), Cohn (1996), Dirks (2001). Gilmartin argues that within this framework, colonial authorities sought to "define a structure of Muslim leadership that would help to stabilize their regime." Prior to the establishment of elections, "they recognized a broad spectrum of influential men, with a range of backgrounds and power bases (often with no connection to Islam) as Muslim 'leaders'” (Gilmartin, 1998: 417-418). These elites retained a significant advantage after the establishment of elections as local kinship networks and powerbases played an important part in candidates' nomination and voters' mobilisation.

${ }^{8}$ We can think for instance of the Simla Deputation (1906), composed of unelected yet influential zamindars, princely rulers and jurists, led by the Aga Khan, who petitioned Lord Minto, the Governor-General of India, to demand greater representation for Muslims in local councils. This deputation is regarded as a major factor behind the adoption of separate electorates for Muslims in the Morley-Minto reforms (1909). 
The Indian form of secularism implemented after independence maintained some of the colonial ways of dealing with religious communities, including by formally, or sometimes more informally, granting a certain representative function to various community organizations. Since 1947, state authorities have adopted different ways of crafting ties with Muslim personalities or organizations-and more generally with minorities. These efforts have resulted, among other things, in the creation of state institutions dedicated to minorities, with the establishment of the Minorities Commission in 1978, and the Ministry of Minority Affairs in 2004. Within this framework, the state appears to be the regulatory authority of the social space of Muslim spokespersons in India. Muslim spokespersons seek to be recognized by the state as legitimately able to make representative claims for Muslims-even when they seek to keep the state out of community matters. We also include as Muslim spokespersons individuals who do not themselves explicitly claim to represent Muslims but whom state authorities identify as privileged intermediaries to address the Muslim community, usually because of their institutional position.

\section{On the notion of social space}

In order to study Muslim spokespersons, we provisionally use the notion of "social space". Another term that we considered was Bourdieu's concept of "social field", which can be defined as "an abstract concept that allows the methodological autonomization of an area of activity defined in a relational ... and dynamic way ..., provided that this autonomization is justified on socio-historical grounds" (Sapiro 2018). The autonomization of art from religion can be taken as an example of this process. We could consider Muslim leadership to be a field, inasmuch as the issue of Muslim representation in India is partly autonomized from two larger fields: politics and religion, in this case Islam. However, the concept of field may not fully apply in our case. It requires certain characteristics which may not obtain here: a sufficient degree of autonomy, a precise description of its internal oppositions and dynamics, and common issues of concern that structure relations within it. Therefore, for the time being, we use the more flexible notion of social space, that is, a space defined by the comparable social characteristics of its members.

\section{Constructing the database}

Who is part of the social space of Muslim representation? In the absence of an existing list of Muslim spokespersons, we have constituted our own database by incorporating the officebearers of organizations that either claim to speak in the name of Muslims or play a significant 
role in Muslims' minority affairs in independent India. ${ }^{9}$ More precisely, we have selected fifteen organizations that state authorities identify as potential representatives for India's Muslim population. We have also included Muslims who held key executive positions in the state apparatus, i.e. Presidents and Vice-Presidents of India as well as Union ministers (see table).

Table 1: Organizations and positions

\begin{tabular}{|c|c|c|}
\hline $\begin{array}{ll}\text { Type } & \text { of } \\
\text { organizations }\end{array}$ & Name of organizations & Positions \\
\hline \multirow{2}{*}{$\begin{array}{l}\text { State minority } \\
\text { institutions for the } \\
\text { management of } \\
\text { community affairs }\end{array}$} & Central Waqf Council (CWC) & Chairperson \\
\hline & Haj Committee (HC) & Chairperson \\
\hline \multirow{4}{*}{$\begin{array}{lr}\text { Muslim organizations } \\
\text { which } \\
\text { authorities regularly } \\
\text { consult on "Muslim } \\
\text { matters" }\end{array}$} & All-India Muslim Personal Law Board (AIMPLB) & $\begin{array}{l}\text { Founder, } \quad \text { President, Vice- } \\
\text { President, General-Secretary }\end{array}$ \\
\hline & $\begin{array}{l}\text { Babri Masjid Action Committee (BMAC) (sub- } \\
\text { organization of the AIMPLB) }\end{array}$ & $\begin{array}{ll}\text { Chairperson, } & \text { Convener, } \\
\text { Spokesperson } & \end{array}$ \\
\hline & $\begin{array}{l}\text { All-India Shia Personal Law Board (AISPLB) } \\
\text { (splinter group of the AIMPLB) }\end{array}$ & President, General-Secretary \\
\hline & All-India Muslim Majlis-i Mushawarat (AIMMM) & $\begin{array}{l}\text { Founder, President, Vice- } \\
\text { President, General-Secretary }\end{array}$ \\
\hline \multirow{2}{*}{$\begin{array}{ll}\text { Central } & \text { Muslim } \\
\text { universities } & \end{array}$} & Aligarh Muslim University (AMU) & Vice-Chancellor \\
\hline & Jamia Millia Islamia (JMI) & Vice-Chancellor \\
\hline \multirow{3}{*}{$\begin{array}{lr}\text { Muslim } & \text { political } \\
\text { parties with elected } \\
\text { MPs }\end{array}$} & All-Indian Majlis-i Ittehad-ul Muslimeen (AIMIM) & President, General-Secretary \\
\hline & All-India United Democratic Front (AIUDF) & $\begin{array}{l}\text { President, General-Secretary, } \\
\text { Member of Central Executive } \\
\text { Committee }\end{array}$ \\
\hline & Indian Union Muslim League (IUML) & President, General-Secretary \\
\hline \multirow[t]{4}{*}{$\begin{array}{l}\text { Socio-religious } \\
\text { organizations }\end{array}$} & Jamiat-ul Ulama-i Hind (JUH) & $\begin{array}{l}\text { President, Vice-President, } \\
\text { General-Secretary }\end{array}$ \\
\hline & Imarat-i Shariah (IS) & Amir, Naib Amir \\
\hline & Jama Masjid Delhi (JMD) & Shahi Imam \\
\hline & Jamaat-i Islami Hind (JIH) & $\begin{array}{l}\text { Amir, Vice-President, Secretary } \\
\text { General }\end{array}$ \\
\hline $\begin{array}{l}\text { Executive positions in } \\
\text { the state apparatus }\end{array}$ & & $\begin{array}{l}\text { Union ministers } \\
\text { Vice-Presidents } \\
\text { Presidents }\end{array}$ \\
\hline
\end{tabular}

\footnotetext{
${ }^{9}$ We wish to acknowledge the work of Ankit Raghav, Md Irfan, and Md Osama in collecting information for the database. We also would like to thank the Centre de Sciences Humaines in New Delhi for its support to this project, particularly through the Challineq project funded by the French ANR.
} 
Conversely, we excluded from this database Muslim figures who are part of organizations that do not make representative claims in the name of Muslims, notably apolitical religious organizations (e.g. Tablighi Jamaat) as well as Muslim business and artistic elites, or Muslim top state functionaries (IAS, IFS, IPS, Supreme Court). For the same reason, we excluded organizations that claim to represent only a section of the Muslim population, either based on caste or gender. This partly explains why there are so few women and low-caste individuals in our database. Moreover, at this stage, we have not included Muslim MPs, MLAs, and state-level ministers (unless they also held a key position in one of the organizations on our list) in order to keep the database within a manageable size range. ${ }^{10}$

\section{Methodological note on Multiple Correspondence Analysis}

All in all, our database counts 164 individuals. We have collected information about their family backgrounds, their education, their careers, and their public lives. More specifically, we have used fourteen active variables related to the positions of power that these individuals occupied and to different forms of socializations (family, religious, political) that help explain how they accessed these positions (see table 2). ${ }^{11}$

On the basis of these variables, we constructed a Multiple Correspondence Analysis (MCA) using the software R and its FactoMiner extension (Lê et al., 2008). ${ }^{12} \mathrm{We}$ also included six supplementary variables, i.e. variables that do not participate in the definition of the space but that are projected on it. We have included as supplementary variables:

a) State of birth, which serves as a proxy for regional origins. The assumption behind the choice of using the state of birth as a supplementary rather than active variable is that places of origin are better understood as bundles of socio-economic properties rather than as black boxes yielding their own consequences (Bourdieu 1993).

\footnotetext{
${ }^{10}$ We may consider including these people in future expansions of the database.

${ }^{11}$ In the rest of the article, we indicate the reference to variables and modalities with square brackets. For example: [org.ed.no].

${ }^{12}$ We constructed the MCA using the Burt method. This method allows for a projection of the cloud of individuals and properties on a single scale and therefore produces easier-to-read results.
} 
b) Membership in non-Muslim political parties (three variables for INC, BJP, other). Unlike the affiliation to a Muslim party, being a member of a non-Muslim party is not a characteristic feature specific to our group.

Table 2: Variables, modalities, and contributions

\begin{tabular}{|c|c|c|c|c|c|c|c|}
\hline Heading & Variable & Modality & $\%$ & $\operatorname{Dim} 1$ & Dim2 & Dim3 & $\operatorname{Dim} 4$ \\
\hline \multirow{9}{*}{$\begin{array}{l}\text { Type of } \\
\text { organization }\end{array}$} & \multirow{2}{*}{$\begin{array}{l}\text { Educational and cultural } \\
\text { (AMU, JMI, ATU) }\end{array}$} & org.ed.no & 78.7 & 1.2 & 3.3 & 0.5 & 0.7 \\
\hline & & org.ed.yes & 21.3 & 4.3 & 12.3 & 2.0 & 2.7 \\
\hline & \multirow{2}{*}{$\begin{array}{l}\text { Religious and community } \\
\text { organization } \\
\text { (JUH, AIMPLB, MMM, JI, IS, JMD, } \\
\text { AISPLB, BMAC) }\end{array}$} & org.rel.no & 55.5 & 9.3 & 0.2 & 0.6 & 0.1 \\
\hline & & org.rel.yes & 44.5 & 11.7 & 0.3 & 0.8 & 0.1 \\
\hline & \multirow{2}{*}{$\begin{array}{l}\text { Government organization } \\
(\mathrm{CWC}, \mathrm{HC})\end{array}$} & org.gov.no & 81.1 & 0.9 & 1.6 & 0.8 & 1.2 \\
\hline & & org.gov.yes & 18.9 & 3.8 & 6.7 & 3.7 & 5.0 \\
\hline & \multirow{3}{*}{$\begin{array}{l}\text { Cabinet ministers \& presidents } \\
\text { (party: INC, BJP, JD, JP) }\end{array}$} & cab.no & 56.7 & 2.0 & 6.4 & 0.5 & 0.9 \\
\hline & & Exec & 29.3 & 7.8 & 3.6 & 1.4 & 0.6 \\
\hline & & MP.LA & 14.0 & 1.5 & 5.5 & 9.9 & 0.5 \\
\hline \multirow{4}{*}{$\begin{array}{l}\text { Prominent } \\
\text { role in the } \\
\text { organizations }\end{array}$} & \multirow[t]{2}{*}{ Multiple affiliations } & multiple.no & 70.1 & 0.0 & 0.4 & 0.1 & 11.4 \\
\hline & & multiple.yes & 29.9 & 0.2 & 0.9 & 0.2 & 26.6 \\
\hline & \multirow{2}{*}{\begin{tabular}{|l}
$\begin{array}{l}\text { Position in top leadership } \\
\text { (president \& general-secretary) }\end{array}$ \\
\end{tabular}} & lead.no & 6.7 & 1.8 & 0.4 & 0.0 & 1.0 \\
\hline & & lead.yes & 93.3 & 0.1 & 0.0 & 0.0 & 0.0 \\
\hline \multirow{2}{*}{\multicolumn{2}{|c|}{$\begin{array}{l}\text { Teaching position in a Muslim university (JMI or } \\
\text { AMU) }\end{array}$}} & univ.no & 93.3 & 0.2 & 0.8 & 0.2 & 0.1 \\
\hline & & univ.yes & 6.7 & 2.7 & 11.4 & 3.0 & 0.2 \\
\hline \multirow{8}{*}{$\begin{array}{l}\text { Political party } \\
\text { membership }\end{array}$} & \multirow{2}{*}{$\begin{array}{l}\text { Muslim party (AIMIM, AIUDF, } \\
\text { IUML, WPI, PP, etc.) }\end{array}$} & party.muslim.no & 87.8 & 0.1 & 0.7 & 3.2 & 0.1 \\
\hline & & party.muslim.yes & 12.2 & 0.3 & 4.7 & 22.9 & 0.6 \\
\hline & \multirow[t]{2}{*}{ INC } & INC.no & 80.5 & & & & \\
\hline & & INC.yes & 19.5 & & & & \\
\hline & \multirow[t]{2}{*}{ BJP } & BJP.no & 95.7 & & & & \\
\hline & & BJP.yes & 4.3 & & & & \\
\hline & \multirow{2}{*}{$\begin{array}{l}\text { Regional or caste-based party (SP, } \\
\text { BSP, RJD, JDU, BLD, etc.) }\end{array}$} & Party.reg.no & 93.9 & & & & \\
\hline & & Party.reg.yes & 6.1 & & & & \\
\hline \multirow{9}{*}{$\begin{array}{l}\text { Religious } \\
\text { belonging }\end{array}$} & \multirow[t]{2}{*}{ Madrasa educated } & madrasa.no & 72.0 & 4.5 & 0.1 & 0.1 & 0.7 \\
\hline & & madrasa.yes & 28.0 & 11.5 & 0.1 & 0.1 & 1.9 \\
\hline & \multirow[t]{7}{*}{ Sect } & Shia & 0.6 & 0.1 & 1.5 & 0.3 & 0.3 \\
\hline & & Shia.12 & 6.7 & 0.8 & 7.0 & 0.5 & 0.1 \\
\hline & & Shia.is & 1.8 & 1.7 & 0.3 & 0.8 & 3.2 \\
\hline & & Sunni & 26.2 & 5.2 & 0.0 & 0.1 & 2.7 \\
\hline & & Sunni.ref & 36.0 & 6.5 & 0.0 & 4.8 & 1.2 \\
\hline & & Sunni.tradi & 10.4 & 0.4 & 2.6 & 20.8 & 0.0 \\
\hline & & n.a. & 18.3 & & & & \\
\hline
\end{tabular}




\begin{tabular}{|c|c|c|c|c|c|c|c|}
\hline Heading & Variable & Modality & $\%$ & $\operatorname{Dim} 1$ & Dim2 & Dim3 & Dim4 \\
\hline \multirow{4}{*}{$\begin{array}{l}\text { Educational } \\
\text { achievement }\end{array}$} & \multirow[t]{4}{*}{ Highest university degree } & degree.no & 34.1 & 8.5 & 0.0 & 3.4 & 1.1 \\
\hline & & Bachelor & 17.7 & 3.0 & 1.9 & 2.1 & 2.4 \\
\hline & & Master & 32.3 & 0.3 & 1.9 & 4.2 & 1.2 \\
\hline & & $\mathrm{PhD}$ & 15.9 & 2.7 & 12.4 & 1.8 & 2.7 \\
\hline \multirow{28}{*}{$\begin{array}{l}\text { Social and } \\
\text { family } \\
\text { background }\end{array}$} & \multirow{2}{*}{ Gender } & Female & 3 & 1.9 & 0.2 & 1.1 & 19.9 \\
\hline & & Male & 97 & 0.1 & 0.0 & 0.1 & 0.6 \\
\hline & \multirow[t]{3}{*}{ From an Ashraf biradari } & ashraf.no & 22.0 & 1.5 & 8.6 & 0.6 & 3.8 \\
\hline & & ashraf.yes & 70.1 & 0.5 & 2.8 & 0.2 & 1.3 \\
\hline & & n.a. & 7.9 & & & & \\
\hline & \multirow{2}{*}{$\begin{array}{l}\text { Leadership position previously } \\
\text { held by a family member }\end{array}$} & heredit.no & 90.9 & 0.3 & 0.1 & 0.8 & 0.4 \\
\hline & & heredit.yes & 9.1 & 2.6 & 1.0 & 8.1 & 4.5 \\
\hline & \multirow[t]{21}{*}{ State of birth } & Andhra Pradesh & 7.3 & & & & \\
\hline & & Assam & 2.4 & & & & \\
\hline & & Bangladesh & 0.6 & & & & \\
\hline & & Bihar & 11.6 & & & & \\
\hline & & Delhi & 4.9 & & & & \\
\hline & & England & 0.6 & & & & \\
\hline & & Gujarat & 0.6 & & & & \\
\hline & & Haryana & 1.2 & & & & \\
\hline & & \begin{tabular}{|l|} 
Jammu $\quad \&$ \\
Kashmir
\end{tabular} & 2.4 & & & & \\
\hline & & Jharkhand & 2.4 & & & & \\
\hline & & Karnataka & 4.3 & & & & \\
\hline & & Kerala & 4.3 & & & & \\
\hline & & Madhya Pradesh & 2.4 & & & & \\
\hline & & Maharashtra & 9.8 & & & & \\
\hline & & Makkah & 0.6 & & & & \\
\hline & & Pakistan & 0.6 & & & & \\
\hline & & Rajasthan & 3.0 & & & & \\
\hline & & Tamil Nadu & 3.0 & & & & \\
\hline & & Uttar Pradesh & 33.5 & & & & \\
\hline & & West Bengal & 2.4 & & & & \\
\hline & & n.a. & 1.8 & & & & \\
\hline \multirow{3}{*}{\multicolumn{2}{|c|}{ Historical Period }} & $1947-1977$ & 22.6 & & & & \\
\hline & & 1978-1998 & 29.9 & & & & \\
\hline & & $1999-2020$ & 47.6 & & & & \\
\hline \multirow{2}{*}{\multicolumn{2}{|c|}{ Awards }} & awards.yes & 6.7 & & & & \\
\hline & & awards.no & 93.3 & & & & \\
\hline
\end{tabular}


c) Time periods. ${ }^{13}$ We used this as a supplementary variable to see if certain types of profiles gained prominence in a specific historical period. Another possibility would have been to make separate MCAs for different time periods. However, the limited size of the population did not allow for it. Moreover, the social characteristics of our population appears to be relatively stable across these time periods (see below).

d) Awards, which serves as a proxy for public recognition.

The active variables are best summarized by the four main dimensions, which respectively account for $33 \%, 21 \%, 11 \%$, and $5 \%$ of the total variance of the variables (i.e. $70 \%$ cumulatively) (see figure 1). Some of the other dimensions could have been added from a purely statistical perspective, but a frequent practice is to stop considering new dimensions when the curve suddenly flattens, which is precisely the case here after the first four dimensions. Moreover, the following dimensions did not add to our understanding of the population under study, which is why we retained only the first four dimensions. ${ }^{14}$

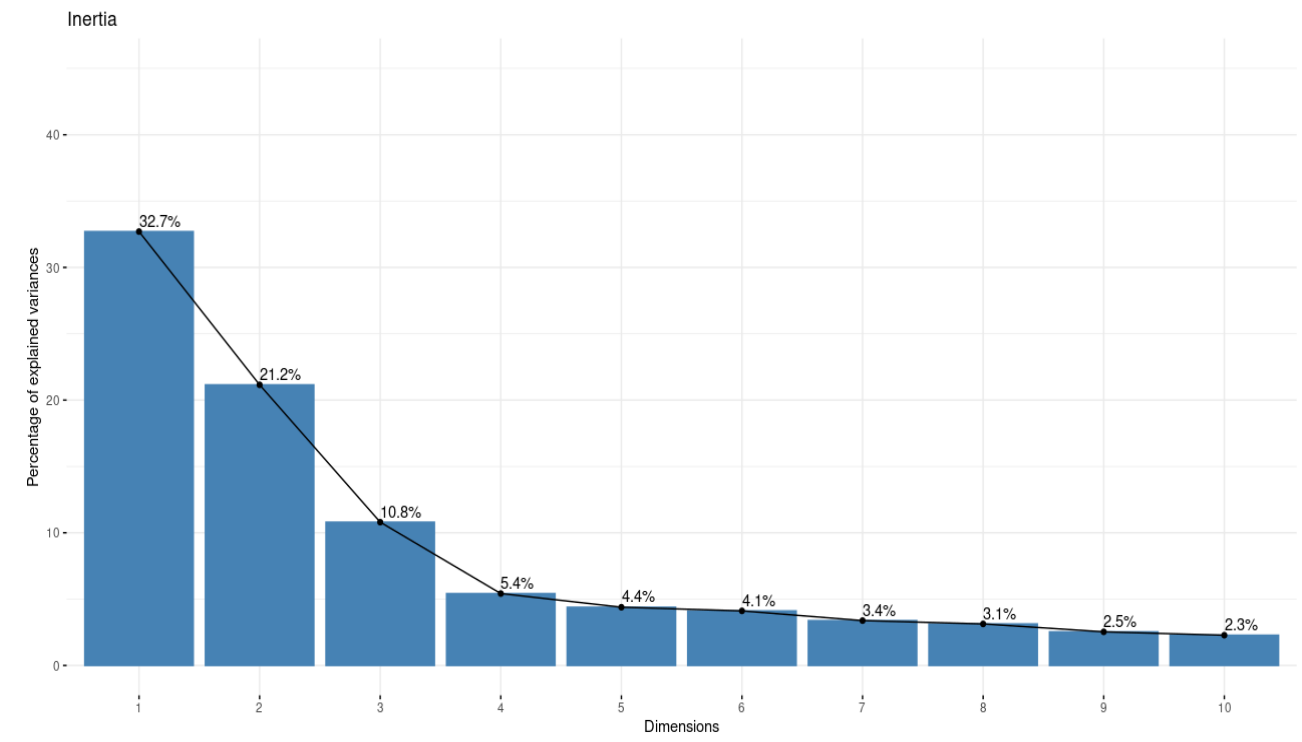

Figure 1: Inertia

In addition to the MCA, we made a Hierarchical Clustering on Principal Components (HCPC), a tool also provided by FactoMiner (see figure 2). It uses the coordinates of the individuals in

\footnotetext{
13 1947-1977 (post-partition years until the end of the Emergency), 1978-1998 (post-Emergency until the first BJP government), 1999-2020 (first BJP government to present-day)

14 The remaining non-available data have been imputed using the missMDA package of R (Josse \& Husson 2016).
} 
the MCA to group them into fairly homogeneous clusters in which individuals share similar characteristics. ${ }^{15}$ We will use these clusters below to examine in greater depth the different types of profiles that emerge in our population.

In the following sections, we will first introduce the four major dimensions of the MCA before presenting the four clusters that result from the hierarchical clustering.

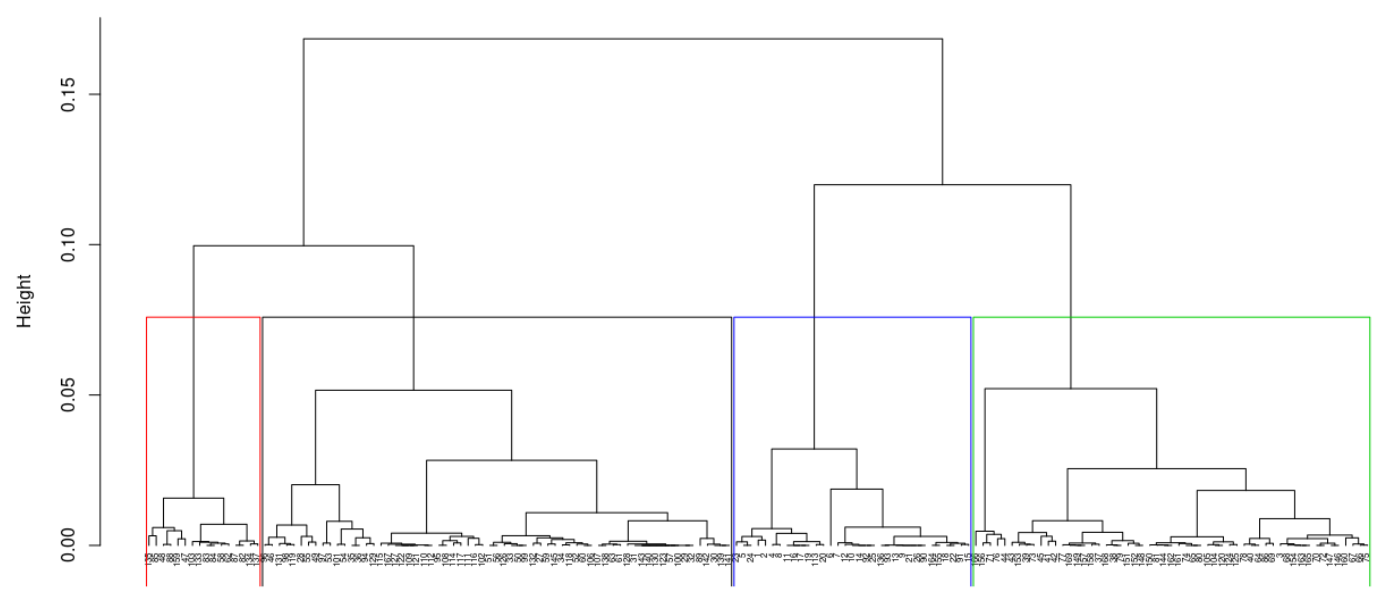

Figure 2: Cluster dendrogram

\section{Four structuring oppositions among Muslim spokespersons}

The major distinction that structures the social space of Muslim spokespersons in India opposes individuals with a religious background to those with a secular profile. What we mean by religious or secular concerns the background of the individuals and does not speak to their public stance in favour or against secularism: a person with a religious background may well express secularist views. India's first education minister, Abul Kalam Azad, is a case in point: he received a religious training, was respected as a theologian, and was an ardent defender of secularism. Besides, one has to keep in mind that each variable is nothing but the barycentre of all the individuals having this property, so that the actual cloud of these individuals may be stretched between different positions. Therefore, the oppositions we are depicting here are ideal-types in the sense of Max Weber. This being said, the first dimension of the MCA appears horizontally on figure 3, with religious individuals on the left and secular ones on the right. Indeed, the variables that statistically contribute the most to this axis

\footnotetext{
${ }^{15}$ To compute the distance between points, we used the most common, Euclidean distance, applied to the four main dimensions of the MCA.
} 
include, first, one's affiliation (or lack thereof) with a religious organization [org.rel.yes and org.rel.no], and whether one has studied (or not) in a madrasa [madrasa.yes and madrasa.no]. In other words, we find on the left those who are affiliated with a religious organization and have studied in madrasa, not in a university (madrasa studies are usually correlated with the absence of a university degree [degree.no]). On the right side of the graph are located those who are not affiliated with a religious organization and who usually studied at university.

Moreover, we find that individuals categorized as reformist Sunnis [sunni.ref] tend to appear on the religious side, while those who are "unspecified" Sunnis are more numerous on the secular side. ${ }^{16}$ This is partly because madrasa-educated individuals are more likely to have an explicit affiliation with reformist organizations, while other Sunnis will not necessarily identify themselves explicitly either with reformists or with traditionalists. Finally, ministers, vice-presidents, and presidents of India [Exec], who occupied top positions in the state apparatus, are logically concentrated on the secular side. They are absent from the religious side of the graph.

The second dimension of the MCA appears vertically on figure 3 and opposes cultural elites (lower section) to the political ones (upper section). The variables that statistically contribute the most to this axis are cultural capital, social status, and the proximity to state institutions. Cultural capital involves being part of an educational organization [org.ed.yes], having a $\mathrm{PhD}$ $[\mathrm{PhD}]$, and teaching at the university level [univ.yes]. Individuals who fulfil these criteria are primarily found among the cultural elites. Social status entails belonging (or not) to Muslim upper caste groups, collectively designated as Ashraf. Ashraf Muslims [ashraf.yes] are present in all groups, especially among cultural and religious elites (below). Non-Ashraf [ashraf.no], who are largely under-represented, are found primarily among the political elites (above). We

\footnotetext{
16 In order to apprehend sectarian distinctions within Sunnis, we have broadly categorized individuals as either traditionalist or reformist. Traditionalists claim to defend Islam as it has evolved in South Asia and uphold practices associated with devotion at Sufi shrines. They can follow either the Hanafi (in North India and the Dekhan) or Shafi (in the Southern coastal regions of India) school of jurisprudence. Reformists tend to rejected many of the practices associated with South Asian Islam, such as shrine worship, although not all reject shrine culture as a whole. They can follow the Hanafi school of jurisprudence (like the Deobandis) or entirely rejects all four fiqh (like the Ahl-i Hadith and the Salafis). The boundaries between these sectarian orientations may at times be hard but are often not so, particularly between Barelvis and Deobandis. Many individuals of North Indian origin could thus not clearly be identified as either Barelvi or Deobandi, and are therefore listed as "unspecified” Sunnis.
} 
may add a sectarian dimension to this distinction: Twelver Shias [shia.12] (who are usually also Ashraf) are particularly well represented among the cultural elites. Finally, the proximity to state institutions is measured through the participation in a governmental organization [org.gov.yes], the holding of a top executive position in the state apparatus (President, VicePresident of India, Union Minister [Exec]), a parliamentary seat [MP.LA], or no such position [cab.no]. Individuals who fulfil these criteria are usually found among the political elites.

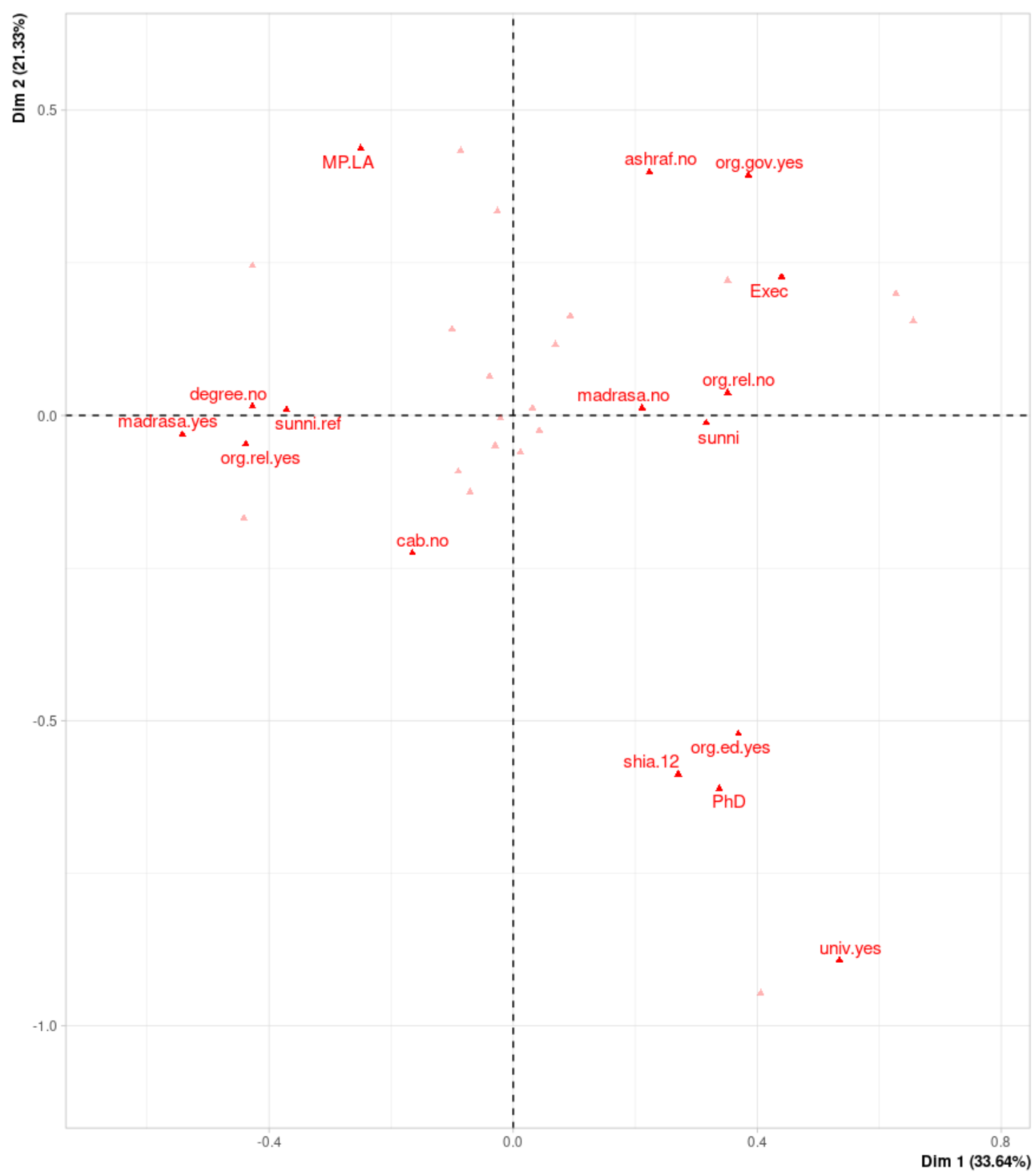

Figure 3: Dimensions 1 and 2

The third dimension of the MCA appears horizontally on figure 4 and opposes Muslim parties to ruling parties, chief among them the INC and the BJP. The variables that statistically 
contribute the most to this axis include the affiliation to a Muslim party [party.muslim.yes] and being categorized as a traditionalist Sunni [sunni.tradi]. Muslim parties are often led by traditionalist Sunnis, which is why these two characteristics appear to be close to each other on the graph. The other significant properties for this dimension are the holding of a hereditary position [heredit.yes], which accounts for the dynastic character of many Muslim parties (like in AIMIM), and being a MLA or a MP. These characteristics are primarily associated with Muslim parties.

Finally, the fourth dimension of the MCA reveals the social hierarchy within the political sphere. This hierarchy appears vertically on figure 4, with the dominant on the upper half of the graph. The modalities that statistically contribute the most to this dimension are one's multipositionality [multiple.yes vs multiple.no], with individuals holding multiple positions located towards to the upper part of the graph, and one's gender, with being a woman [female] located high up on the graph. Women in South Asia are certainly underrepresented in the political sphere, but the few who are present in this field sometimes hold very high positions. One can think of course of Indira Gandhi and Sonia Gandhi in India or Benazir Bhutto in Pakistan. In our population, Mohsina Kidwai and Najma Heptullah present impressive political careers. This explains why the "female" modality appears among the dominant, on the upper side of the graph. The female modality also appears on the left of the graph. This is due to the fact that the few women included in the database are usually associated with ruling political parties rather than with religious organizations or Muslim parties, which have left little place for female leaders outside of women-specific bodies.

Moreover, another significant variable in the fourth dimension is the holding of a hereditary position [heredit.yes], a situation which clearly brings a surplus of prestige and power. Lastly, one may observe a slight gradation in the university degrees, starting at the bottom with the Bachelor, continuing upwards with Master, and finishing at the top with $\mathrm{PhD} .{ }^{17}$ Thus, one's educational attainment may at times exert an influence on the position that one is able to access.

Apart from the variables on which the MCA was computed, we have projected supplementary variables on the graph, such as time periods and states of birth. These variables do not actively

\footnotetext{
17 'Degree.no' means no university degree. It is often associated with madrasa-educated people, so it does not necessarily mean that individuals have a lower education level than university graduates.
} 
contribute to the dimensions but they provide an additional layer of information by indicating variations across time and space. One of the most striking elements that the MCA brings out is the relative stability of our population across time (as well as its social homogeneity). Indeed, the points representing time periods on figure 5 remain close to the centre, which suggests that the global structure of our population has remained relatively stable, with for instance little change in the proportion of Ashraf to non-Ashraf (see table 3). Some variations, however, are visible, and will be discussed below.

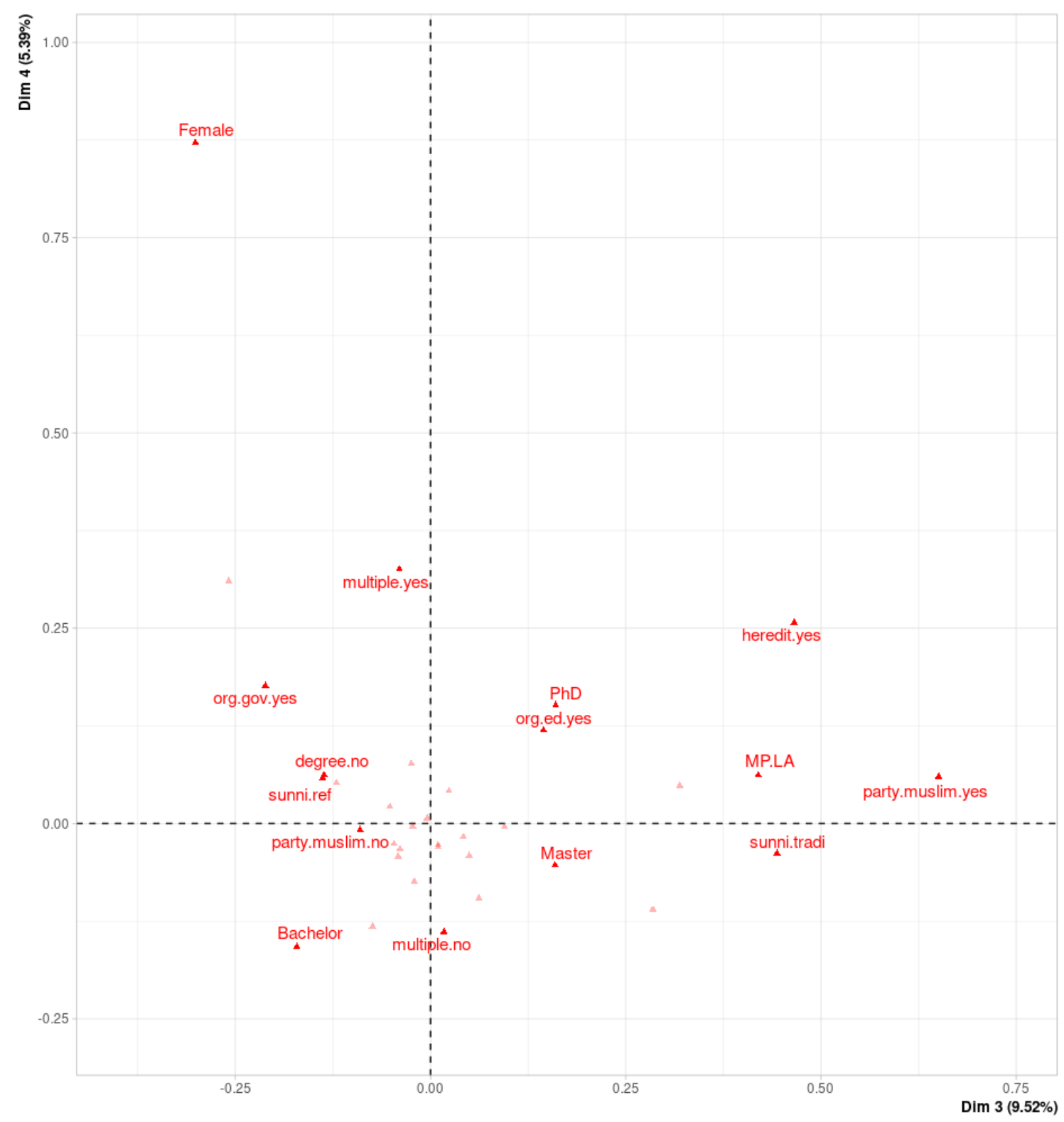

Figure 4: Dimensions 3 and 4

One also notes the overrepresentation of North Indian leaders in our list (34\% are from Uttar Pradesh alone). The "Hindi belt" thus remains the heartland of Muslim politics (Kudaisya, 2006): a large section of the organizations and individuals who claim to speak for all Muslims 
hail from this region. By contrast, Muslim-led organizations elsewhere (notably in Bengal or in Kashmir) tend to have a stronger regional focus, which explains their underrepresentation in our database. ${ }^{18}$ North Indian individuals are particularly well represented among the educated religious or cultural elites. UP thus appears in an intermediate situation on the first dimension: the many UP-born individuals are mainly split between religious leadership and educational institutions, even though some of them are to be found in political elites too. By contrast, the MCA shows that people from Kerala and Tamil Nadu reach leadership positions primarily in community-based politics.

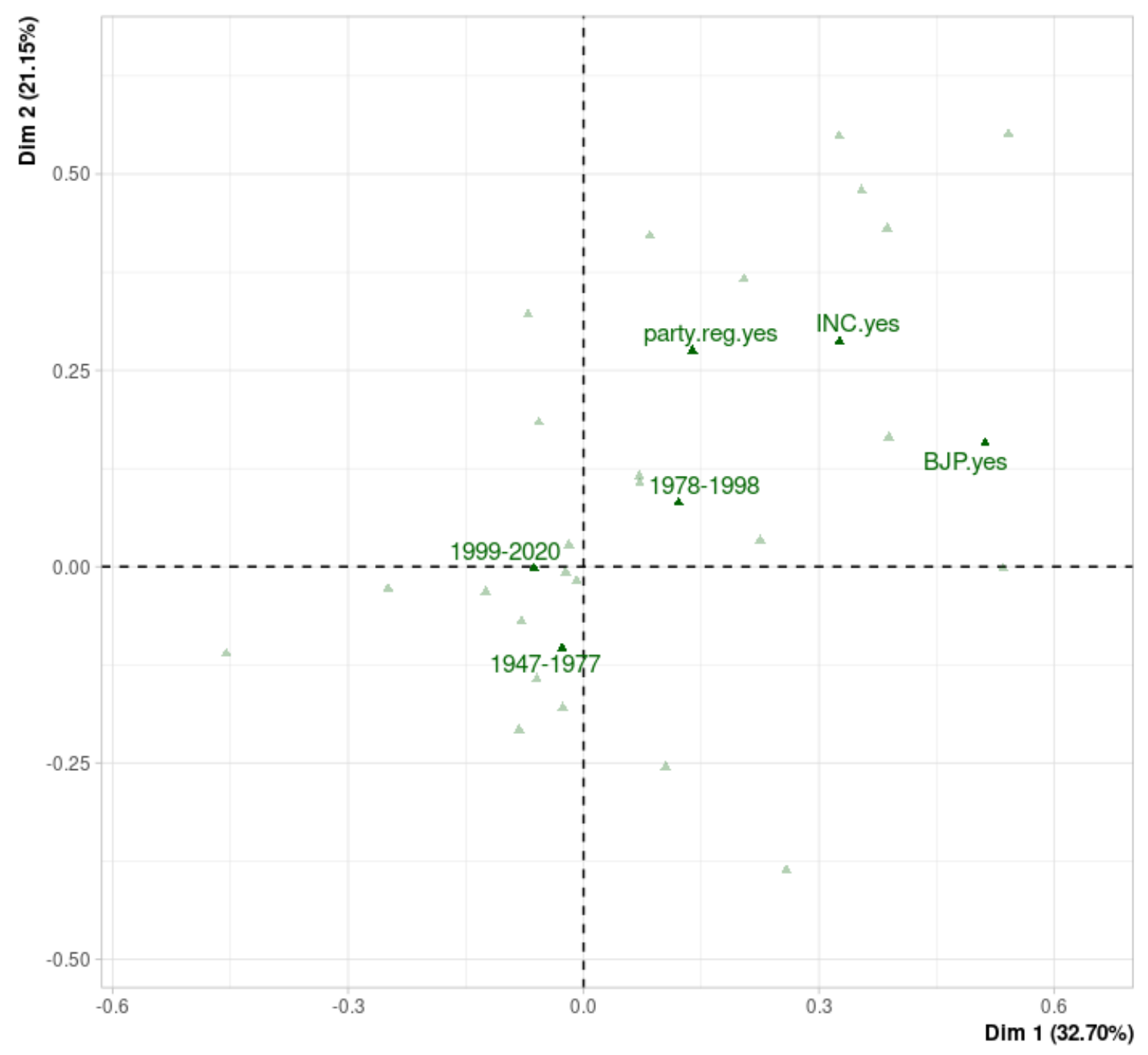

Figure 5: Time periods on dimensions 1 and 2

\footnotetext{
${ }^{18}$ Very few individuals in our database come from these states, which is why these states' position on the MCA should be interpreted as a provisional one.
} 
Table 3: The stability of the proportion of Ashraf

\begin{tabular}{|l|l|l|l|l|}
\hline & $\mathbf{1 9 4 7 - 1 9 7 7}$ & $\mathbf{1 9 7 8 - 1 9 9 8}$ & $\mathbf{1 9 9 9 - 2 0 2 0}$ & Total \\
\hline ashraf.no & 18.9 & 26.5 & 20.5 & 22.0 \\
\hline ashraf.yes & 70.3 & 65.3 & 73.1 & 70.1 \\
\hline$<\mathrm{NA}>$ & 10.8 & 8.2 & 6.4 & 7.9 \\
\hline Total & 100.0 & 100.0 & 100.0 & 100.0 \\
\hline
\end{tabular}

\section{III. "Muslim voices" in state circles}

What kind of sub-groups can be identified among Muslim spokespersons in India? Hierarchical clustering allows us to distinguish inside four main groups that emerge on the basis of these four dimensions.

We will first examine Muslim elites in state circles, ${ }^{19}$ who appear on the right side of figure 6 . These two groups share a common secular background in the sense that they received a nonreligious education [madrasa.no, Bachelor, Master or $\mathrm{PhD}$ ] and do not usually belong to Muslim religious groups or pressure groups [org.rel.no]. This means that their authority as Muslim spokespersons is not premised upon their religious background nor upon their affiliation with Muslim community groups but rather on their affiliation either with ruling parties [INC.yes, BJP.yes] or with state-sponsored Muslim universities [org.ed.yes]. These individuals do not necessarily claim to speak for Muslims themselves. In fact, they are sometimes derided as "Sarkari Muslims", i.e. as "government stooges", who do not care for their community. But they do at times act as Muslim spokespersons within the state apparatus, or are expected to do so.

\footnotetext{
${ }^{19}$ We are borrowing this expression from the Sachar Committee Report: "Many persons the Committee interacted with, felt that lack of adequate "Muslim voice" in the government, even in local selfgovernment bodies and similar other grassroots institutions has resulted in a situation that Muslims have lagged behind. In their view, political participation and representation in governance structures are essential to achieve equity." (Sachar Committee Report, p.24).
} 
These individuals, sometimes criticized as "government stooges", are often identified in a more positive light as "nationalist Muslims," committed to preserving the unity of the nation. These two expressions reflect ongoing tensions about Muslims' place in the Indian nationstate. On the one side, the assumption is that the one who prioritises loyalty to the state ends up being disloyal to his/her community. On the other side, there is a tacit understanding that one who focuses primarily on the community jeopardises the unity of the nation and reinforces Muslims' isolation. The individuals who belong to these two clusters have clearly privileged state-sponsored institutions over community-specific representation.

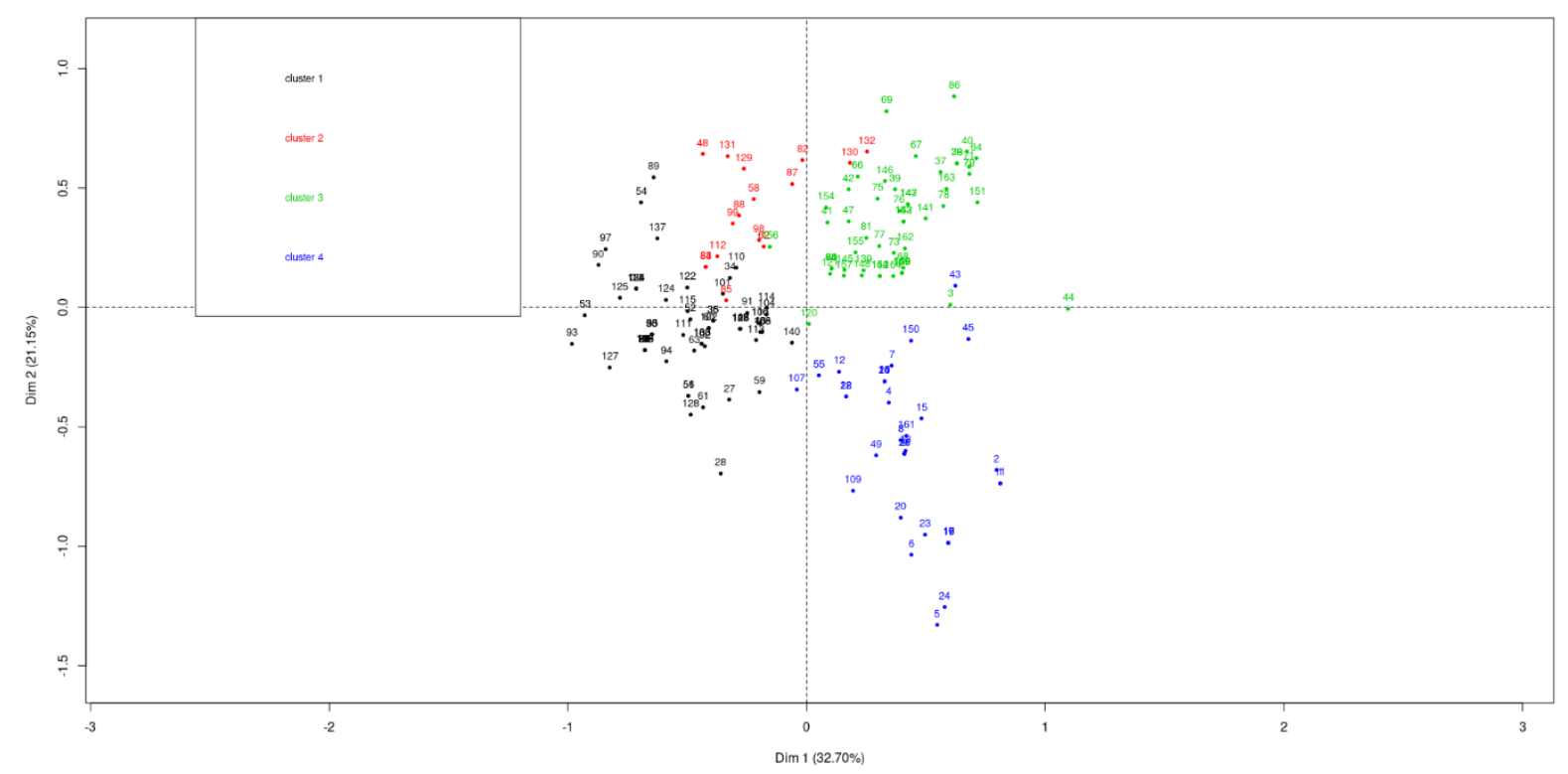

Figure 6: The four clusters on dimensions 1 and 2

\section{Muslim politicians in ruling parties}

The first of these two clusters corresponds to Muslim politicians in ruling parties. These individuals generally hailed from dominant groups, either Ashraf elites in North India or other dominant castes outside the Hindi belt. More importantly, they usually came from the Congress party. This affiliation with the Congress, which remained the ruling party at the Centre for a long time, gave them access to power. Many of these individuals thus held positions in governmental organizations, in central government or were even appointed as President or Vice-President of India. Some of them, the most successful political leaders, combined different types of positions within ruling circles $^{20}$ : in addition to ministerial

\footnotetext{
${ }^{20}$ Multipositionality is the most important variable in dimension 4.
} 
portfolios, they may also have held positions in Parliament or in state assemblies. It is usually within this group that the government selected individuals to head organisations specially dedicated to Muslims, such as the Central Waqf Council, the Haj Committee or the Ministry of Minority Affairs (created in 2006, under Congress rule). ${ }^{21}$

\section{Regional dignitaries}

Within this cluster, we can identify three types of profiles. The first one corresponds to local dignitaries outside the Hindi belt associated with the Congress. They consist of regional elites, who belong to locally dominant castes. In continuity with the colonial period, after independence the Congress relied on these local dignitaries to expand the party's influence at local and regional level. Many of these individuals have led successful professional careers in parallel to their political careers - as businessmen, chartered accountants, lawyers or journalists, which further enhanced their local influence.

These individuals are primarily engaged in regional or local politics. We can take for example Mohammad Amin Khandwani from Bombay. Khandwani came from the Halai Memon community, a small and prosperous merchant community from the western coast. He belonged to an important business family involved in real estate. In parallel, he was involved in Anjuman-i-Islam, an educational organisation promoting education for Muslims, which helped him build his influence among local Muslims. This social capital helped Khandwani make a place for himself within the Congress. He remained a member of this party throughout his political career, working at local level (as municipal councillor or as leader of the Municipal Congress Party) and at regional level: he became General Secretary and Vice President of Bombay's Regional Congress Party in the 1970s. His affiliation with the Congress allowed him to reach Maharashtra's State Assembly in 1980. Soon after, he became Chairman of two governmental organisations associated with Muslims: the Maharashtra State Minorities Commission and the Haj Committee, based in Bombay.

\footnotetext{
${ }^{21}$ The time period variable on the figure 5 suggests that this group became more prominent between 1978 and 1998. Both Congress and Janata governments appointed a significant number of Muslims as Cabinet Ministers or Ministers of State (a post created in 1977) in this period. Political parties often considered the so-called "Muslim vote" as instrumental in Congress's 1977 defeat. In this context, to appoint Muslim ministers appeared to be one of several tactics to attract Muslim voters. However, Congress's rivals usually appointed Muslims in junior positions: the "Muslim vote" was not their main priority.
} 
Some of these local dignitaries moved from regional to central politics, reaching Parliament, central-level governmental organisations, or cabinet positions. We can think for instance of Abdul Rahman Antulay, who started his career in Maharashtra. Much like Khandwani, Antulay belonged to a locally dominant caste, Konkani Muslims, and was trained as a lawyer, a high-profile profession. He pursued a long career in Congress, starting at regional level (Maharashtra's Legislative Assembly, state government) before alternating between regional and central politics (Rajya Sabha in 1976, Maharashtra's Chief Minister in 1980, Lok Sabha in 1989, Union minister in 1995). In 2006, he became the first person to hold the position of Minister of Minority Affairs, a position which he combined with that of Chairperson of the Central Waqf Board. Thanks to these multiple positions, Antulay thus became one of the main Muslim faces of the Congress at local and central level during this period.

\section{Congress's core (Muslim) leadership}

Beside these local dignitaries coming from outside the Hindi belt, we can identify a group of individuals who formed part of the Congress's core leadership. These individuals are usually Ashraf from North India, India's political heartland. As zamindars, lawyers or government servants, they came from the same social circles as many prominent national-level Congress leaders, most notably Nehru. They shared a strong, long-term connection with the Congress. A number of them participated in freedom struggle or their family's older generations did. As Muslims, this history is particularly significant. It means that they belonged to the North Indian Muslim elites who did not join the Muslim League nor moved to Pakistan. These individuals generally remained committed to the Congress and to the idea of India as a secular, composite nation, even at the time of partition. After independence, they often occupied important positions at the Centre, either in Parliament or in the government. They did not necessarily take up positions specifically tagged for Muslims but their being Muslim mattered: it helped the Congress show its non-majoritarian character.

A good example would be Rafi Ahmad Kidwai, a prominent Congress leader, very close to Nehru. Like him, Kidwai came from a well-established zamindari family who had had access to English education as well as to the colonial state apparatus. His father was a government servant and his uncle a lawyer. Kidwai joined the Congress's anti-colonial movement at an early stage: in 1920, he took part in Gandhi's Non-Cooperation movement as well as the Khilafat movement, led by Gandhi's Muslim allies. This allowed him to buttress his reputation within the Congress. In 1926, he was elected to the Central Legislative Assembly and later 
became UP's Home Minister (1946). After independence, he joined Nehru's central government, thus standing at the heart of India's state apparatus.

We find politicians with a similar kind of profile in the next generation of Congress leaders. Take for example Khursheed Alam Khan, again a North Indian Ashraf with multiple positions at the heart of the state apparatus. Khan was elected to the two chambers of Parliament and was part of the central government before he became Governor of Goa. He was also appointed Chancellor of Jamia Millia Islamia, often regarded as a prime symbol of "nationalist Muslims" close to the Congress. Khan's example illustrates the long-term influence of families who had played a prominent part in the Congress during freedom struggle. Khan's father-in-law was none other than Zakir Husain, a prominent educationist close to Gandhi and Nehru who successively headed Jamia Millia and Aligarh Muslim University, before he became VicePresident and President of India in the early independence period. This prestigious family legacy also helped Khan's son, Salman Khurshid, access top positions in the Congress, in Parliament and in the central government, some tagged for Muslims (Minister of Minority Affairs, Central Waqf Council), others not (Minister of External Affairs). Before this, Khurshid had made a name for himself by defending Muslim Personal Law's autonomy during the Shah Bano controversy (1985). ${ }^{22} \mathrm{He}$ epitomised, along with his father and his grandfather, Congress's core Muslim leadership, whom the party often regarded as go-to persons to address Muslim citizens, whether or not they held positions specifically tagged for Muslims.

\section{From Congress to BJP}

A third type of profile emerges in this cluster: politicians who opted for the BJP after 1977, usually after an early career within the Congress. The BJP offered them opportunities, first as Congress's main opponent and later as the ruling party. Sikander Bakht's trajectory epitomises this shift. Bakht first fought under the Congress banner at municipal level (1952). He then gradually shifted to the right side of the political spectrum. In 1969, he joined Congress $(\mathrm{O})$, a faction that opposed Indira Gandhi, then quit Congress altogether after the Emergency to join the Janata Party and then the BJP (1980). This was a rewarding move for Bakht. While he had never held a high position with the Congress, he won a seat as MP in 1977, the year when he moved to Janata Party. He then occupied top positions within the BJP (General Secretary, Vice-President). In the late 1990s, when the party rose to power at the

\footnotetext{
${ }^{22}$ For an insight into his position on this issue, see Khurshid (2014: 23-26).
} 
Centre, Bakht became Union Minister as well as Chairman of the Central Waqf Council. In contrast to most Congress's Muslim leaders, Bakht did not come from a dominant caste: he belonged to the Qureshi butcher community. This may partly explain why he did not receive prime attention within the Congress. Joining the Congress's opponents opened up better opportunities for him, especially after the BJP became the ruling party.

In contrast to Bakht's gradual shift, others had a more sudden change of political affiliation. Take for instance Najma Heptulla. Born in a Sayyid Dawoodi Bohra family related to Congress president Maulana Azad, Heptulla was a perfect example of Congress's high-status core Muslim leadership. ${ }^{23}$ She pursued a long and successful career within this party: she was elected four times to the Rajya Sabha and held key positions in the party (general secretary, spokesperson). However, she started moving closer to the BJP after it won the general elections in 1999. ${ }^{24}$ Heptulla eventually joined the BJP in 2004, just before the general elections, and secured a good position for herself in the party. She became one of the BJP's Vice-Presidents as well as one of its main Muslim faces after she was appointed Minister of Minority Affairs and Chancellor of Jamia Millia Islamia. ${ }^{25}$

Despite the ideological differences between the Congress and the BJP, both ruling parties thus identified their senior Muslim members as Muslim and often gave them positions accordingly, for instance by appointing them at the head of institutions specifically dedicated to Muslims or to minorities. This reflects, of course, the ongoing salience of candidates' caste or religious backgrounds in Indian political representation since the colonial period. In the case of Congress, it also reflects, more specifically, the party's efforts to enhance their secular credentials among Muslim voters so that they can claim to speak for all Indians. This is clearly not a priority for the BJP, which relies overwhelmingly on the Hindu vote (Jaffrelot, 2019: 48).

\footnotetext{
${ }^{23}$ Sayyids claim descent from Prophet Muhammad and are generally considered at the top of the Muslim social hierarchy (Gautier and Levesque, 2020).

${ }^{24}$ In 2000, the BJP-led National Democratic Alliance appointed her at the head of the Indian Council for Cultural Relations, a prestigious governmental organization.

${ }^{25}$ Najma Heptulla is one of the handful of women (Mohsina Kidwai, Syeda Anwara Taimur, Rashida Haque Chaudhury, Najma Akhtar) in our database, who all belong to non-religious organisations. Ruling parties and educational institutions have made limited space for these women endowed with a high-status background, a high educational level, and/or family connections in politics, whereas women remain absent from top positions in Muslim parties or religious organisations, outside of Muslim organisations specifically dedicated to women.
} 
Yet, even the Hindu-right party sometimes tries to appeal to sections of Muslim voters, either by appointing Muslim candidates locally ${ }^{26}$ or by reaching out to religious leaders, usually from minority groups among Muslims (Mahmudabad, 2018).

\section{Educational elites}

For Congress, these Muslim politicians had an important role to play in securing Muslims' support and in consolidating national integration. The heads of state-sponsored Muslim universities endorsed a similar role, especially in the early years of independence, when large sections of India's Muslim political elites moved to Pakistan. ${ }^{27}$ Much like their political counterparts, these educational elites neither went to religious schools nor joined Muslim parties or religious organisations. Unlike them, however, they did not necessarily join a political party (if they did, they usually opted for Congress). They privileged instead other channels-i.e. educational institutions, and sometimes cultural organizations-to promote national integration. ${ }^{28}$

These educational elites usually belonged to a smaller social circle as compared to Muslim politicians in ruling parties. Most of them hailed from university-educated North Indian Ashraf elites, ${ }^{29}$ who had stayed in India after partition, i.e. from the same social circles as Congress's core Muslim leadership. They also shared with them strong ideological affinities: many of these educational elites were pro-Congress, sometimes pro-Left, and were firmly committed to the idea of India as a secular composite nation.

\footnotetext{
${ }^{26}$ See for instance The Indian Express (2021).

${ }^{27}$ Figure 5 shows that the point representing the period from the independence to the end of the Emergency (1947-77), is approximately located midway between religious leaders and cultural elites, which accounts for the importance of these two groups in that period.

${ }^{28}$ Some of these individuals were also associated with Anjuman-i Taraqqi-i Urdu, an association which promotes the Urdu language. We have not included this organization in our database as it does not claim to represent Muslims and opposes the idea that Urdu is exclusively a Muslim language.

${ }^{29}$ The HCPC (table on relations between groups and variables) shows that an overwhelming majority of individuals in these clusters were born in UP.
} 


\section{Vice-Chancellors with an academic background}

We can distinguish three main subgroups in this cluster. First, Vice-Chancellors with a mainly academic background $[\mathrm{PhD}$, univ.yes]. These individuals came from cultured North Indian Ashraf-often Shia-families. If they obtained support from the government to head Jamia and Aligarh, it was not only thanks to their academic trajectories but also thanks to their ideological compatibility with the ruling parties.

This was the case of Mushirul Hasan, a famous historian, known for his pro-Congress, leftof-centre leanings. Hasan came from a highly educated North Indian Sayyid Shia family. His father was himself an established historian at Jamia. Mushirul was educated at AMU and Cambridge before he joined Jamia as a teacher. Hasan exemplified the notion of the Muslim secular nationalist intellectual. He vigorously defended the idea that Muslims had a central role to play in the nation's building and strongly criticised both Hindu and Muslim communal forces who threatened the "secular consensus" à la Nehru. Thanks to his academic reputation, his close knowledge of Jamia and his ideological compatibility with Congress, Hasan rose to the highest ranks of the institution: he was appointed as pro-Vice-Chancellor and later as Vice-Chancellor, a position which required government support. Although Hasan did not himself claim to speak for Muslims, his positions at the head of one of the two central Muslim universities lent him special visibility and authority to speak on Muslim issues. When Jamia's students attacked him in 1992 for having supposedly endorsed Salman Rushdie's Satanic Verses, they highlighted the symbolic and political significance of his position as pro-ViceChancellor: "We do not bother when such views are expressed by someone assuming a general position. But when a person holding a key post or heading a [Muslim] institution creates controversy by expressing his views, how can it be ignored?" They feared that his views against the ban on Rushdie's novel may "give the impression to the Government that it should review its decision." 30 For them, Hasan was more than a historian or a public intellectual. Because of his position at the head of Jamia, he was a privileged interlocutor for the government on Muslim issues.

\footnotetext{
30 'Agitation would continue till our demands are accepted', Interview of Badruddin Quraishi, Union President, Radiance, 21-27 June 1992.
} 


\section{Politicians-cum-academics}

The political value of Muslim universities appears even more clearly in the case of educationists engaged in politics (usually within the Congress) even as they remained invested in educational institutions. We can think for instance of Zakir Husain, who went on to occupy the state's top office (see above) or Bashir Husain Zaidi, who headed AMU in the 1950s. Much like Hasan, Zaidi hailed from a highly educated Sayyid Shia family of Uttar Pradesh. His father taught economics at Delhi's Anglo-Arabic College. Zaidi was himself trained at AMU and Cambridge (again like Hasan). Throughout his career, he alternated between educational and political positions. He first took up an academic position at AMU before embarking on a political career in the princely state of Rampur. After independence, Zaidi successfully fought the 1952 elections under the Congress banner. In 1956, he was chosen to replace Zakir Husain at the head of AMU. Given Aligarh's status as India's main Muslim university and its past association with the Muslim League, it greatly mattered to Congress to have like-minded individuals at the head of the institution to transform the erstwhile "arsenal of Muslim India" 31 into a symbol and an instrument of national integration (Gautier, 2017).

\section{State officers turned VCs}

This also explains why, beside politicians-cum-academics, we find a large number of top civil servants, and even a few army generals, at the head of the two universities. These individuals came from the same social background as other members of the educational elites, i.e. North Indian Ashraf elites with secular credentials. As Vice-Chancellors, they were expected to contain "communal" elements and to restore law and order on campus (Arora and Mathur, 1992). Having served as Vice-Chancellors, especially at AMU, enhanced their status as Muslim spokespersons for state authorities. Thus, several of them were appointed to state committees or to institutions in charge of minority affairs. For instance, Naseem Ahmad joined Haryana's State Waqf before he chaired the National Commission for Minorities, just like Hamid Ansari, whom Congress later anointed as India’s Vice-President.

Much like Muslim politicians in ruling parties, these educational elites therefore became the "Muslim faces"-"Muslim chehre" in Hindi or Urdu-of state institutions. These two groups

\footnotetext{
${ }^{31}$ This is an expression that Jinnah used in reference to AMU's students. Mohammad Ali Jinnah, Speech at Aligarh Muslim University, 10 March 1941.
} 
did not necessarily claim to represent Muslims themselves. Some of them even feared that they may be tagged as "communal" if they spoke on Muslim issues (Hasan, 1997: 194-195). But this does not mean that their Muslim identity did not matter. Their mission could be, first, to "prove" the secular character of state institutions or of the ruling party. This was especially true in the case of the Congress which had tried, since the colonial period, to dispel the idea that they formed a Hindu party. Their mission could also be, second, to promote "enlightened" secular values among Muslims-read an attachment to the nation's unity and developmentas opposed to so-called obscurantist and communal ideas, which gave priority to the community's autonomy. Through these different channels, these individuals endorsed the idea, powerfully formulated by Maulana Azad at the time of partition, ${ }^{32}$ that it was by joining non-Muslim organisations, not by forming separate communitarian organisations, that Muslims would be best equipped to defend a secular composite India.

\section{A public engagement centred on Muslimness}

If spokespersons with a secular background have occupied prominent positions and therefore constitute an important part of our database, several groups are characterized by a type of public engagement explicitly centred on being Muslim. They include people engaged in religious and community organizations, as well as in Muslim political parties. Grouped in clusters 1 and 2, they are located on the left side of figure 6 and thus clearly apart from elites with a secular background.

\section{Clerics and community activists}

Cluster 1 brings together people who have a close association with Muslim community and religious organizations listed in our database [org.rel.yes]. They are not generally associated with the educational and governmental organizations in our list [org.ed.no, org.gov.no]. Most of them have received a religious training in a madrasa [madrasa.yes]. This explains why most of them have no university degree [degree.no]. Those with no madrasa degree hold positions in community organizations rather than in religious organizations. They can be called "community activists," who, despite their secular training, display more in common with religious leaders than with the secular leaders of the first two clusters. One of the

\footnotetext{
${ }^{32}$ See his famous speech at the Jama Masjid on 24 October 1947.
} 
characteristics they share with clerics is that they generally stay out of ruling and political circles. They do not hold ministerial positions [cab.no] nor do they belong to ruling political parties [INC.no, BJP.no]. Finally, the individuals in this cluster share three important characteristics regarding their family background-features that they also share with many of the secular leaders previously described. They generally come from Ashraf families (mostly Sayyid and Shaikh) [ashraf.yes], are Hanafi Sunni [sunni], and hail from north India [Uttar Pradesh, Rajasthan, Bihar].

\section{Clerics}

The individuals of this cluster can be further sub-divided into two main groups: clerics involved in religious organizations, and secular individuals active in community organizations-here again, the adjective secular points to the background of individuals and should not be confused with a secularist public stance. The core of this cluster is formed by Deobandi ulama [sunni.ref] who belong to Ashraf families from North Indian states, mainly Uttar Pradesh, Rajasthan and Bihar. Most of them tend to keep out of political circles but some prominent figures reach a national renown that allows them to play a political role-like the Madani family. However, even when they are co-opted by the state or by political parties, the authority of these ulama rests primarily on their religious grounding. The state co-opts them precisely because they already have a degree of authority as Muslim religious figures-a role that is sometimes inherited and that endows them with a certain legitimacy as representatives of Muslims.

Mahmood Madani embodies many of the characteristics of the group of Deobandi ulama. His family claims Sayyid status, hails from Uttar Pradesh, and speaks Urdu, like other educated Ashraf Muslim elites from North India. Born in 1964, Mahmood Madani is the grand-son of Husain Ahmad Madani, the leading figure of the Jamiat Ulama-i-Hind whose family has retained control over the organization since before India's independence. Therefore, Mahmood Madani is an heir in a family of prominent religious scholars. Many of the Deobandi ulama who are office-bearers in religious and community organizations follow in their fathers' footsteps by training at Deoband [heredit.yes], even though few inherit positions of power comparable to that of Mahmood Madani.

Indeed, Mahmood Madani also stands out in this group of Deobandi ulama. Unlike most of them, his public engagement is not limited to religious and community organizations. Because his family controls the major organization of Deobandi ulama, it has long been influential in 
politics-they have claimed and been granted an unofficial role as spokespersons for Muslims. Mahmood Madani's father Asad Madani, who led the JUH for 32 years, also served three terms as member of Parliament in India's upper house (Rajya Sabha). He did not, however, obtain this position through an electoral victory but through a nomination by the Congress. Mahmood Madani's approach is different as he directly pursues political power. In his search for political backing, he joined several parties-the Samajwadi Party, and then the Rashtriya Lok Dal, thanks to which he became an MP in 2006.

More importantly, Mahmood Madani sought to steer the JUH away from the influence of the Congress, a move that led to a split in JUH (2008). Unlike his uncle, Arshad Madani, who aims to maintain the organization's long-lasting association with the Congress party, Mahmood Madani has shown his readiness to join other political parties and to build alliances with a variety of political actors (such as the Trinamool Congress in West Bengal). This willingness to compromise for alliances has brought upon him much criticism. Madani is also accused of being less vocal against the BJP than against other Muslim leaders like Asaduddin Owaisi and Azam Khan. Furthermore, he has supported the creation of a separate Muslim political party in Assam (2006), which campaigns for Muslim votes against the Congress. This party, the AllIndia United Democratic Front (AIUDF), is led by another Deobandi alim, Badruddin Ajmal, who sided with Mahmood Madani in the 2008 split. Madani's political engagement and the split that resulted in the JUH can be seen as a generational shift that pins those who hold on to an alliance with the Congress against a younger group that, in the aftermath of the Babri Masjid demolition and the rise of Hindutva, has sought to experiment with new forms of politics for Muslims. The younger generation engages in Muslim politics in a way that explicitly appeals to voters as Muslims and seeks to bring them on one platform. Thus, Mahmood Madani appears to be a kind of "activist alim," seemingly more invested in the search for political power and public notoriety than in the religious scholarship on which his legitimacy is supposed to rest.

Muhammad Wali Rahmani offers another interesting example of the group of Deobandi ulama who combine religious authority and high social status. Wali Rahmani was born in a Sayyid family whose members are custodians (sajjada nashin) of a Sufi shrine in Munger (Bihar). His religious position was thus hereditary "by right": the office of custodian of a Sufi shrine has become hereditary all across the subcontinent. Moreover, he is part of a dynasty of religious scholars. His grandfather was the head of one of the most important north Indian madrasas, the Nadwat-ul Ulama in Lucknow. His father, Minnatullah Rahmani, was also one 
of the founders of the AIMPLB. Like Madani, Rahmani thus combined a hereditary position as a religious leader with an elevated social status.

Like most Deobandi ulama in this group, Wali Rahmani's public engagement depended on his legitimacy as a religious figure. His hereditary position as the head of a spiritual organization, the Khanqah-i Rahmani, which also runs a large madrasa in Munger, allowed him to enter politics without stepping into the electoral fray: he was a nominated member of Bihar's Legislative Council from 1974 to 1996. Yet his involvement in politics remained limited to his home state of Bihar and outside top ruling circles. In parallel, Wali Rahmani constructed a large network of welfare organizations, shouldered on his religious network. In 1996, he launched the Rahmani Foundation, a charity organization that runs schools and hospitals across Bihar.

Wali Rahmani combined multiple positions in Muslim religious and community organizations (AIMPLB, AIMMM, IS). He was also appointed to various government committees that deal with minority affairs, such as the Central Waqf Council, the Urdu Advisory Committee Bihar, or the Monitoring Committee for Minority Education of the Ministry of Human Resource Development. Moreover, he was involved in several Muslim educational institutions (AMU's Court, Vice-Chairman of the Maulana Azad Foundation). Finally, Wali Rahmani also participated in public life by launching a newspaper in Urdu, Eisar.

Thus, a figure like Wali Rahmani, despite a notable involvement in public life, remained out of electoral politics and ruling political parties. Much like Madani, his authority rested on his hereditary position, his religious training as a Deobandi, and his elevated social status-not on his association with the state. On this basis, he could occupy multiple positions of power in various Muslim religious and community organizations, construct his own charity network, and be co-opted by the state as a Muslim spokesperson, be it in Bihar's upper house or on various committees for minority affairs.

We might add that while Deobandi ulama have long supported the secular conception of the nation promoted by the Congress, they aspire to be recognized by the state as the legitimate authority to regulate minority affairs. This is particularly true in relation to Muslim Personal Law: the ulama wish to keep the state out of the religious realm, and for this, they need the state to recognize them as the legitimate arbiters of Muslim Personal Law. Madani and Wali Rahmani's reliance on their religious authority and their co-optation by the state as Muslim representatives is a good illustration of this conception of secularism. 
In parallel to Deobandi ulama, who occupy a prominent place, a smaller number of Barelvi religious figures form a very similar group. Such Barelvi religious leaders include, for instance, Syed Shah Fakhruddin Ashraf, associated with the shrine of Kichaucha Sharif in Uttar Pradesh. What mainly distinguishes them from Deobandi ulama is their different religious training (not associated with Deobandi madrasas), the fact that they are systematically linked to Sufi religious institutions (dargah, khanqah), and that they are even less associated with the political domain than their Deobandi counterparts.

\section{Community activists}

Apart from religious figures, cluster 1 includes many "community activists", who are dedicated and active members of community organizations. Their social background is similar to that of the ulama: they are mainly Sunni Muslims from North India, Urdu-speaking, and generally, though not always, from Ashraf families. Unlike the ulama, however, they have received a secular rather than a religious education, and are involved in community organizations like the AIMMM and the JIH rather than religious organizations. Religious organizations such as the JUH or the IS are initiatives by clerics. Community organizations, on the other hand, have a wider scope: they pursue a community-specific agenda (whether it pertains to socio-moral reform or to collective representation) but are open to non-clerical members. We thus find in these organizations community activists who hold university degrees but little or no madrasa education. Many of them pursued successful careers in higher education and journalism and often have a deep journalistic or literary engagement with Urdu.

Community activists may adopt varying political positions. This is reflected, for instance, in the heterogeneous character of the AIMMM, a platform organization which has aimed since its inception to bring together a wide range of Muslim personalities, ranging from Congress supporters (N. M. Anwar) to members of the Jamaat-e-Islami (Muhammad Salim Engineer). Important examples of community activists active in the AIMMM include two its presidents: Zafarul Islam Khan, the former editor of the Milli Gazette and former Chairman of the Delhi Minority Commission, and Navaid Hamid, who has been associated with multiple NGOs working for Muslims in India, such as the South Asian Council for Minorities, the Association for Promoting Education and Employment of Indian Muslims, or the Movement for Empowerment of Muslim Indians. Some community activists may even lean towards the Left, particularly among a subgroup active in literary and journalistic circles. A good example of this profile is the journalist Amanullah Khan. Born in Aligarh (Uttar Pradesh) in 1951, he 
comes from a Sunni, Pathan, Urdu-speaking family. Khan first studied in Kolkata and then obtained a Master's degree from Aligarh Muslim University. The interesting aspect about his career is that even though he received a secular university education, he remained involved in Muslim organizations throughout-although never in religious organizations. Fairly early in his journalistic career, he became chairman of the Islamic Journalism Society (1983-85). Later, he remained involved in Muslim educational organizations, such as the Muslim Education Trust, the All-India Education Movement, as well as the Hamdard group launched by Sayyid Hamid. His appointment as General-Secretary of the AIMMM in 2010 thus comes as a result of a long engagement in community organizations. Another example of community activists associated with literary circles is Masoom Morababadi, a reputed Urdu journalist who became the General-Secretary of AIMMM in 2014-15 and stands out as one of the few non-Ashraf in this group.

\section{Leaders of Muslim political parties}

Among those for whom Muslimness is part of their public engagement, cluster 2 comprises individuals who are active in Muslim political parties. This group stands out quite visibly on the figure 6: it is very clearly located in the political sphere (as opposed to the clerical sphere), and on the side of Muslim parties, as opposed to ruling parties.

The main characteristic that unites the individuals in this cluster is that they have been officebearers in the Muslim political parties listed in our database [party.muslim.yes]. Consequently, they are not part of governmental minority affairs organizations [org.gov.no]. They also tend not to hold top positions with major educational institutions [org.ed.no]. Some of these individuals have become prominent political figures and have held legislative mandates [MP.LA], but their influence is mainly contained to regional politics outside of the Hindi belt. Indeed, these individuals are usually born in southern and eastern states like Kerala, Andhra Pradesh (particularly in Hyderabad, which is now in Telangana ${ }^{33}$ ), and Assam, which correspond to the main geographical bases of the three Muslim political parties.

\footnotetext{
${ }^{33}$ For convenience and consistency across time, we have used the political borders of 2014 to name the state of birth in the database. The same applies for international borders (hence, a person born in Dhaka before 1947 will be marked as being born in Bangladesh). Hence, a person born in present-day Telangana will be indicated as born in Andhra Pradesh.
} 
In terms of religious and social background, the individuals in this group tend to be Sunni, more often traditionalist [sunni.tradi]-particularly in South India-than reformist, except of course in the AIUDF, launched by a Deobandi alim. Many leaders come from privileged castes (Owaisi family in Hyderabad, Shihabuddin family of Panakkad in Kerala), but overall, the Ashraf are in smaller proportion than in cluster 1 (clerics and community activists) or 3 (secular educational elites) and less represented than average in the database. This is particularly true for Assam, where Sylheti Muslims (of lower social/caste status) are at the forefront of the AIUDF. In addition, individuals in this cluster have a greater tendency towards hereditary positions: many occupy a position that was previously held by a family member [heredit.yes]. Finally, the individuals in this cluster tend to have received a secular university education [master] rather than a religious education.

Three subgroups can be identified in this cluster: prominent families that have historically opposed the politics of the Congress party; the recent assertion of Deobandi ulama active in Assam; and secular individuals who have risen up in Muslim political parties.

\section{Historical opposition to the Congress in South India}

Figures that are emblematic of this group belong to the old generation of Muslim political leaders in South India who opposed the Congress's secular politics before partition, and revived Muslim political parties after independence. ${ }^{34}$ This is true of the two families that dominate Muslim parties in South India-the Owaisi family in the AIMIM in Hyderabad, and the Shihabuddin family of Panakkad in the IUML in Kerala. In Kerala, two Sayyid (locally called Thangal) families have been at the forefront of Muslim politics since the 1950s, the Bafaquis and the Shihabuddins. Syed Abdurahiman Bafaqui Thangal joined the All-India Muslim League in 1938 when he participated in local elections. After independence, he joined the IUML at the time of its creation in 1948. He gradually rose in the party until he took it over in 1972, but passed away the following year. Since then, the Shihabuddin family of Panakkad has dominated the party either directly (Syed Muhammad Ali Shihab Thangal) or by placing its protégés (such as P.K. Kunhalikutty). In Hyderabad, a figure similar to Bafaqui Thangal is that of Abdul Wahid Owaisi, who took over the (then) MIM (now AIMIM) in 1957, and whose family has dominated the party since then. He too belonged to a privileged caste (Shaikh) that claims foreign origins. These political leaders share one more important

\footnotetext{
${ }^{34}$ Although, somewhat paradoxically, the IUML in Kerala now ends up being an ally of the Congress.
} 
characteristic: they belong to traditional Sunni elites who have tended to oppose reformist movements. Thus, the Shihabuddin family are religious leaders who represent the traditionalist Sunni Shafi Islam ${ }^{35}$ of Kerala (called the Samastha EK faction) that has been challenged since the early twentieth century by the Salafis of the Kerala Nadvathul Mujahideen and by the JIH (Osella and Osella, 2008). As for Owaisi, he was a Sunni Barelvi, although his descendants-and particularly his grandson Asaduddin Owaisi, who has recently acquired pan-Indian prominence-are generally careful not to make their sectarian affiliation visible, privileging instead a broader Muslim identity.

\section{Recent political assertion of Muslims in Assam}

In recent years, some Muslims in North and Northeast India have also attempted to bring Muslim voters together and away from the Congress party. This is notably the case in Assam, where the AIUDF was established in 2006. Two main elements distinguish the members of AIUDF from their South Indian counterparts. Unlike the Thangals of Kerala and Owaisis, who come from traditional local elites and lead well-established organizations, the AIUDF is a recent political party whose members often belong to lower-status groups (many of them are of Bengali or Sylheti origin) and are reformist Sunnis. Indeed, the AIUDF was founded by Badruddin Ajmal-a Deobandi maulana and business entrepreneur-and is therefore closely associated with the JUH and the Deobandi network in Assam. However, it is close to the Mahmood Madani faction of JUH, which has distanced itself from the Congress to pursue a more assertive form of Muslim politics-in which voters are wooed as Muslims and Muslim political parties attempt to build a political base in order to put pressure on and negotiate with mainstream parties. The AIUDF thus represents a form of Muslim politics that seeks to break away from the historical pro-Congress politics of the JUH.

Despite its differences with IUML and AIMIM, the AIUDF also illustrates the strength of the dynastic pattern. A striking example of the importance-and limits-of political inheritance is that of Abdur Rahman Ajmal, the son of Badruddin Ajmal, the founder of AIUDF. Abdur Rahman is included in our database because he is a member of the Executive Council of the party. Like his father, he studied in Deoband, after which he started undergraduate studies at Jamia Millia Islamia, which he never completed. After this, he interned for a year in his

\footnotetext{
${ }^{35}$ Most South Asian Muslims follow two of the four Sunni schools of jurisprudence: the Hanafi fiqh for most of the subcontinent, and the Shafi fiqh for the Southern coastal regions.
} 
father's perfume business in Dubai. He was then elected MLA at the age of 28, but he turned out to be an unpopular representative who could not face public pressure in his constituency (he was blamed for not acting against corruption). He thus did not run a second time. Like political heirs of traditional elites in AIMIM and IUML, Abdur Rahman reached this position thanks to his father. Unlike other heirs, however, he proved unable to retain it.

\section{New political figures}

The third and final subgroup of this cluster is composed of new political figures who have reached prominence even though they do not come from traditional elites or political dynasties. These include, for instance, two personalities that have played an important role in the 2021 assembly elections in Kerala and Assam, respectively P.K. Kunhalikutty in the IUML, and Md Aminul Islam in the AIUDF. Both are General-Secretary in their party, while the positions of President are occupied by the hereditary leaders or founders (Badruddin Ajmal in AIUDF, Hyderali Shihab Thangal in the IUML). Both have a secular background. P.K. Kunhalikutty is a Mappila ${ }^{36}$ from northern Kerala, close to traditionalist Sunni Shafi Islam, who received a secular education in Commerce and Business Management. As for Md Aminul Islam, he is trained as a lawyer and has not received any advanced religious education. Unlike many other members of his party, he bears no visible religious signs (beard or prayer cap).

Both these men gradually rose to prominence in their respective parties. Kunhalikutty started politics during his higher education, when he joined the student wing of the IUML (the Muslim Student Federation). He became Chairman of the Malappuram Municipal Corporation at the precocious age of 29 , and has since then received the support of the Panakkad Thangal family that controls the IUML. In April 2021, he was elected for the eighth time to the Kerala Assembly and appointed leader of the legislative party. He has become one of the main pillars of the IUML in Kerala, and has also occupied ministerial positions in the state government in the past. Similarly, Md Aminul Islam has come to play an important role in AIUDF: apart from his post as General-Secretary, he is also the party's spokesperson and as such makes important media announcements-on matters of pre-election alliances, for instance.

However, the influence of this type of first-generation politicians is largely limited to regional politics: they may hold MLA seats and sometimes ministerial positions in state governments,

\footnotetext{
${ }^{36}$ The term Mappila has over time been restricted to Muslims in northern Kerala-although at some point it used to indicate a much broader category of people that included Jews and Christians.
} 
but generally not MP seats nor central ministership. Similarly, they may combine their political role with other positions in governmental organizations for Muslim affairs (Waqf, Haj), but this involvement is usually limited to the state level. Kunhalikutty, for instance, did a stint as MP, but it did not prove successful. As a result, he resigned from his seat and decided to run for the state assembly elections instead. Despite these limitations, these two profilesP.K. Kunhalikutty and Md Aminul Islam-indicate a new form of Muslim politics, in which non-hereditary secular leaders can rise to prominence in Muslim political parties.

\section{Conclusion}

This article proposes a delineation of the social space of Muslim spokespersons in India and a typology of its subgroups. We define Muslim spokespersons as individuals who have the capacity to claim to represent Muslims and to receive from the state a certain degree of recognition of that claim. Most of the individuals in our population share certain characteristics: they tend to come from the Urdu-Hindi speaking regions of North India, they usually belong to privileged status groups and are overwhelmingly male. In order to probe beyond this apparent uniformity, we used a multiple correspondence analysis to identify the major fault lines within the population.

Muslim spokespersons in India are thus divided between secular individuals associated with state or state-sponsored organizations, and those engaged in the public sphere as religious or community activists. This opposition mirrors Congress's secular nationalism that defines itself in contrast to "religious communalism," an opposition which structured much of India's political discourse for several decades after independence.

The second structuring opposition highlighted by the MCA pins the political against the educational spheres. The educational sphere is not apolitical, far from it. State-sponsored Muslim universities present alternative platforms, outside religious organizations and political parties, to reach out to the Muslim population or to speak in its name. For this reason, those who hold top offices in these institutions come to be seen as privileged intermediaries between state authorities and part of the Muslim population, even when they do not themselves claim to speak for Muslims.

The third major fault line distinguishes ruling political parties, who exert power at the Centre, from Muslim political parties, whose are regionally anchored and rarely access executive positions (they remain in the opposition). Among Muslims who accede to power circles, many 
are closely associated with the Congress' form of secularism and management of religious diversity. Others, who are associated with the BJP, politically oppose the Congress, yet participate in similar forms of minority representation. Muslims who do not accede to these power circles include members of regional and Muslim parties, which either bear a long-term legacy of opposition to the Congress, predating independence, or represent a recent search for Muslim political autonomy.

\section{Field or social space?}

In the introduction, we asked whether our population constituted a field. We used instead the more flexible notion of social space. At the present stage of our reflection, we may give a more precise answer to this question. First of all, we do not face a field in the classical sense of the term (Bourdieu and Nice, 2018; Weber, 1996). Our individuals are first and foremost embedded in the two fields of religion and politics that structure our population. It is only at the juncture of these two well established fields that the Muslim leadership issue might arise and partly autonomize itself from purely religious and political issues to form a new field.

Second, there are indeed some elements that point towards a form of autonomization. In particular, all the individuals and organizations in our database have to position themselves via-à-vis the State, which appears to act as the main regulatory authority in determining who can be considered to be a Muslim spokesperson.

However, these elements remain limited. This is why we propose the notion of potential field to describe the situation more adequately. Christian Topalov (1999) has used the idea of "weak field" to depict the situation of French reformers at the end of the nineteenth century: their discussions and large conferences gave birth to a real but temporary social space with its own vocabulary, institutions, and stakes. We are not in this kind of configuration: there are neither statements on common issues that respond to one another, nor institutions (newspapers, journals, organizations) shared by all the members of our population. Antoine Vauchez (2008) argues in a similar vein that the lawyers invested in European law form a weak field, but one blessed with a strong position since "they tend to occupy a 'structural hole' (Burt, 1995), bridging and mediating otherwise conflicting institutions and groups". Again, our population does not occupy such a role, since it is split between politicians, religious scholars, and university members that act in separate domains. Therefore, the field we have depicted remains until now a potential one: it could emerge as a real field, if its members were to unite by adopting position statements on common issues and by creating shared institutions. 


\section{State-sponsored secularism}

What does this tell us about state-sponsored secularism in India? State authorities feel the need to turn towards Muslim leaders to address Muslim citizens because they tend to see the Muslim population as a separate group. State authorities co-opt leaders of Muslim religious and political organisations as potential intermediaries, thereby reinforcing the authority of these individuals as Muslim representatives. At the same time, ruling parties create a space within the party, governmental organizations, and educational institutions for ideologically compatible Muslim individuals to emerge as spokespersons for the Muslim community.

Our analysis also points to various forms of contestation of this system. First, religious scholars may engage with this form of state-sponsored secularism, but their aim is often to prevent the state from stepping into religious and community affairs. Second, Muslim political parties contest the role given to Muslims as a co-opted minority and want to constitute Muslims into a political bloc that has bargaining power and can choose its alliances.

If we adopt Saward's terminology, we can argue that not only do Muslim spokespersons make (makers) the claim that they (subjects) represent the Muslim community (object) in front of the state (audience). State authorities themselves are "makers" of representative claims in the sense that they foster different types of "subjects"-from religious leaders to leading educationists or elected politicians-as representing the "Muslim community" (object).

We therefore need to take into greater consideration the performative role of state authorities in shaping the "subjects" of these representative claims, i.e. Muslim leaders, as well as their role in shaping the "object" of these claims, i.e. the "Muslim community".

\section{Who is absent? Biases in Muslim representation}

One of the limitations of the database is of course that it cannot include everyone and therefore has biases. However, we would like to understand these biases as revealing of those that actually exist among Muslim spokespersons in spite of their claims to represent all Muslims.

Who is absent? Some parts of India (West Bengal, Jammu and Kashmir) are hardly represented in the database, although they have significant Muslim populations. This is largely due to the fact that Muslims from these regions have their own religious and cultural organizations that are autonomous from all-India Muslim organizations and that they do not 
have political parties that are explicitly Muslim (and even less so that aim to build an all-India Muslim constituency).

Besides, marginalized caste groups among Muslims are hardly represented: this reinforces the claim made by Pasmanda groups that privileged social groups among Muslims keep holding positions of power in organizations that claim to represent all Muslims-but are therefore not representative (in the sense of descriptive representation) of the whole Indian Muslim population.

Including such groups in the future will thus make our database possibly less representative of internal power imbalances among Muslim spokespersons, yet more representative of Indian Muslims as a whole. 


\section{References}

Ahlquist JS and Levi M (2011) Leadership: What it means, what it does, and what we want to know about it. Annual Review of Political Science 14. Annual Reviews: 1-24.

Ahmed H (2019) Siyasi Muslims: A Story of Political Islams in India. Penguin Random House India Private Limited.

Ahmed H (2021) Imagined realities: some facets of Muslim leadership in India. The Telegraph, 30 October. Kolkata. Available at: https://www.telegraphindia.com/opinion/somefacets-of-muslim-leadership-in-india/cid/1836492 (accessed 15 November 2021).

Boltanski L (1973) L'espace positionnel : multiplicité des positions institutionnelles et habitus de classe. Revue française de sociologie 14(1): 3-26. DOI: 10.2307/3320321.

Bourdieu P (ed.) (1993) La misère du monde. Paris: Seuil.

Bourdieu $\mathrm{P}$ and Nice $\mathrm{R}$ (2018) Pascalian Meditations. Available at: https://search.ebscohost.com/login.aspx?direct=true \&scope $=$ site $\& \mathrm{db}=$ nlebk $\& \mathrm{db}=\mathrm{nlab}$ $\mathrm{k} \& A N=1793660$ (accessed 11 November 2021).

Brass PR (1974) Language, Religion and Politics in North India. London; New York: Cambridge University Press.

Burt RS (1995) Structural Holes: The Social Structure of Competition. Cambridge, Mass.: Harvard University Press.

Chiriyankandath J (1992) 'Democracy'under the Raj: Elections and separate representation in British India. fournal of Commonwealth \& Comparative Politics 30(1). Taylor \& Francis: 39-63.

Citizens Against Hate (2020) The Dismantling of Minority Education: Police Violence in Aligarh Muslim University and Jamia Millia Islamia. November. Available at: https://citizensagainsthate.org/wp-content/uploads/2020/12/Dismantling-ofMinority-Education-Violence-against-JMI-and-AMU.pdf.

Farooqui A (2020) Political representation of a minority: Muslim representation in contemporary India. India Review 19(2). Taylor \& Francis: 153-175.

Gautier L and Levesque J (2020) Introduction: Historicizing Sayyid-ness: Social Status and Muslim Identity in South Asia. Journal of the Royal Asiatic Society. Cambridge University Press: 1-11. DOI: 10.1017/S1356186320000139.

Gilmartin D (1998) A magnificent gift: Muslim nationalism and the election process in colonial Punjab. Comparative Studies in Society and History 40(3). Cambridge University Press: 415-436.

Hasan M (1997) Legacy Of A Divided Nation: India's Muslims From Independence To Ayodhya. Boulder, Colo: Westview Press.

Jaffrelot C (2019) A de facto ethnic democracy? Obliterating and targeting the other, Hindu vigilantes, and the ethno-state. In: Chatterji AP, Hansen TB, and Jaffrelot C (eds) 
Majoritarian State. How Hindu Nationalism Is Changing India. London: Hurst Publishers, pp. 41-67.

Khurshid S (2014) At Home in India: The Muslim Saga. Carlsbad: Hay House. Available at: http://rbdigital.rbdigital.com (accessed 12 November 2021).

Kitschelt H and Wilkinson SI (eds) (2007) Patrons, Clients and Policies: Patterns of Democratic Accountability and Political Competition. Cambridge, UK; New York: Cambridge University Press.

Kudaisya G (2006) Region, Nation," Heartland": Uttar Pradesh in India's Body Politic. SAGE Publishing India.

Lê S, Josse J and Husson F (2008) FactoMineR: an R package for multivariate analysis. fournal of statistical software 25(1): 1-18.

Mahmudabad AK (2018) War on Terror and The Quest for The Acceptable Muslim. News18, 11 March. Available at: https:/www.news18.com/news/opinion/opinion-the-war-onterror-and-the-quest-for-the-acceptable-muslim-1685445.html (accessed 11 November 2021).

Morimoto K (2012) Sayyids and Sharifs in Muslim Societies: The Living Links to the Prophet. London/New York: Routledge.

Osella F and Osella C (2008) Introduction: Islamic Reformism in South Asia. Modern Asian Studies 42(2/3): 247-257.

Pandey G (2012) The Construction of Communalism in Colonial North India. 3rd ed. Oxford: Oxford University Press.

Sapiro G (2018) Field Theory from a Transnational Perspective. In: Medvetz T and Sallaz JJ (eds) The Oxford Handbook of Pierre Bourdieu. New York: Oxford University Press.

Saward M (2006) The representative claim. Contemporary political theory 5(3). Springer: 297318.

Shah LGZU (2018) The Sarkari Mussalman: Life and Travails of a Soldier Educationist. 1st ed. New Delhi: Konark Publishers Pvt.Ltd.

The Indian Express (2021) BJP nominates eight Muslim candidates in Okha municipality. 27 September. Available at: https://indianexpress.com/article/india/bjp-nominates-eightmuslim-candidates-in-okha-municipality-7536205/ (accessed 12 November 2021).

Topalov C (1999) Laboratoires du nouveau siècle(la nébuleuse réformatrice et ses réseaux en France, 1880-1914). Civilisations et sociétés. Editions de l'école des hautes études en sciences sociales.

Vauchez A (2008) The Force of a Weak Field: Law and Lawyers in the Government of the European Union (For a Renewed Research Agenda). International Political Sociology 2(2): 128-144. DOI: 10.1111/j.1749-5687.2008.00040.x.

Weber M (1996) Sociologie des religions (tran. J-P Grossein). Paris: Gallimard. 
Wright TP (1964) Muslim Legislators in India: Profile of a minority elite. The fournal of Asian Studies 23(2): 253-267. 